\title{
An assessment of global resources of rocks as suitable raw materials for carbon capture and storage by mineralisation
}

\author{
T.P. Bide ${ }^{1 *}$, M.T. Styles and J. Naden \\ ${ }^{1}$ British Geological Survey, Keyworth, Nottingham NG12 5GG, UK \\ tode@bgs.ac.uk, mts@bgs.ac.uk, jna@bgsac.uk \\ * Corresponding Author. TP Bide, tode@bgs.ac.uk, +44 1159363273
}

KEYWORDS: Ultramafic rocks; Carbon dioxide sequestration by mineralization; Serpentine; Olivine.

\begin{abstract}
Carbon capture and storage by mineralisation (CCSM) is a method proposed for capturing $\mathrm{CO}_{2}$ by reacting it with magnesium in ultramafic rocks to form carbonate minerals and silica. Large quantities of magnesium silicate rocks are required for this process and to demonstrate the feasibility, and adequately plan for the development and supply of mineral resources, their locations and quantities must be known. This study attempts to globally define the spatial extent and quantity of resources that could be used for the CCSM processes and to asses, if based on resources, this could be a viable, widely applicable $\mathrm{CO}_{2}$ sequestration process. It has been estimated that around 90 teratonnes of material is available. This is sufficient to capture global $\mathrm{CO}_{2}$ emissions for over 700 years at current levels of output and highlights the enormous resource. Even if only a small part is utilised, it could make a significant impact on $\mathrm{CO}_{2}$ reduction. The majority of the resource is contained within ophiolitic rocks. The study further attempts to split CCSM resources into altered (serpentine-rich rocks) and unaltered (olivine-rich rocks) due to the different processing requirements for these rock types. CCSM is likely to be of most use in areas with no access to underground geological $\mathrm{CO}_{2}$ storage or for small operations where underground storage is not practical. This study demonstrates that substantial resources are available and their supply is unlikely to be a constraint.
\end{abstract}

\section{Introduction}

Carbon capture and storage (CCS), is a process considered vital for controlling the rise in anthropogenic $\mathrm{CO}_{2}$ emissions and, thereby mitigating, climate change. This is largely focused on geological sequestration by injection of $\mathrm{CO}_{2}$ into porous sedimentary rocks where the $\mathrm{CO}_{2}$ is held in pore spaces or dissolved in intragranular fluids. Rock sequences with sufficient storage capacity and minimal potential for leakage are typically contained within sedimentary basins, the global distribution of which, are shown on Figure 1. This demonstrates that large areas of the globe do not have access to geological storage. CCSM is a potential method of $\mathrm{CO}_{2}$ capture and storage that might 
be particularly applicable in those places that lack nearby sedimentary basins suitable for $\mathrm{CO}_{2}$ injection. The CCSM process has received less scientific research and technological development than geological storage, thus it is difficult to anticipate the relative cost and efficiency of the two processes in the future. It is possible that CCSM could be a complementary $\mathrm{CO}_{2}$ capture and storage technology and may provide a viable alternative for countries without suitable opportunities for geological storage or for smaller local $\mathrm{CO}_{2}$ sequestration. However, if the CCSM technology develops to a point, where it imposes a similar cost to underground storage, it could be much more widely applicable, either in parallel or as an alternative. The main advantage of CCSM is that the $\mathrm{CO}_{2}$ is permanently captured in solid minerals that are stable for millions of years, with no possibility of leakage. This in turn makes the technology less risky and more acceptable to the general public.

The principle of CCSM, the process by which $\mathrm{CO}_{2}$ reacts with divalent metal cations (mainly magnesium and calcium) to form carbonate minerals, was first proposed by Seifritz (1990). The basis of the process is the reaction of magnesium and calcium silicate feedstock minerals with $\mathrm{CO}_{2}$ to form respective carbonate minerals.

Large quantities of feedstock material, rich in divalent cations, are required for the carbonation reaction as 2-4 tonnes of rock are required for each tonne of $\mathrm{CO}_{2}$ stored. The only elements present in sufficient quantities that form stable insoluble carbonates are magnesium and calcium. Most of the calcium, near the earth's surface, is already in the form of carbonate, in limestone, hence the main candidate as a source of cations is magnesium, that is largely present in silicate minerals. Some calcium might be sourced from industrial waste materials (Renforth et al., 2011, Sanna et al., 2012), but the amounts available are relatively small and could only supply local $\mathrm{CO}_{2}$ capture plants. To achieve significant $\mathrm{CO}_{2}$ capture on a global scale, feed material must come from naturally occurring $\mathrm{Mg}$-rich silicate rocks, known as ultramafic rocks.

For CCSM to be considered as a viable option for carbon sequestration on a large scale the location, volumes and properties of resources suitable for feedstock material must be known. Several regional studies on the distribution of these resources and matching known resource areas to $\mathrm{CO}_{2}$ emitters have been undertaken (Picot et al., 2011, Krevor et al., 2009, Voormeij and Simandl, 2004, Mani et al., 2008, Bodénan et al., 2006 and Renforth 2012). However, to date, no study on quantification of the potential resources available for CCSM on a global scale has been performed. Information on global resources will increase confidence as to the feasibility of this method of capturing $\mathrm{CO}_{2}$ emissions and will assure the industry developing the technology that sufficient resources exist to make the process viable.

This study estimates the total global resources of land-based ultramafic rocks at or near the earth's surface that are suitable for CCSM feedstock material. Information from regional and global geological maps were combined with assumptions regarding the spatial distribution, typical composition and bulk properties of the resources, based on type localities and published literature. These assumptions are detailed in the methodology section. This information will allow industry and policy makers to make informed decisions regarding the viability and suitability of CCSM as a method of carbon capture and as an alternative to geological storage. Also, by mapping the global distribution of CCSM feedstock material further spatial analysis was possible, such as the relationship of resources to areas with potential for, or lack of, geological storage and the relationship of resources to $\mathrm{CO}_{2}$ emitters. This is of significant importance when considering the 
large quantity of feedstock materials required and the associated environmental / economic cost of transport and disposal of material (although this may be offset if a commercial use is found for endproducts). The total resource estimated in this study is the available geological resource calculated mostly using generalised information from published literature and geological mapping. The method employed could be used for country wide or regional estimates where more detailed and specific information is available and economic and environmental aspects can be factored in; but this is not realistic on a global scale.

\subsection{Fundamentals of the CCSM process}

The mineral transformations involved in CCSM occur spontaneously in nature (Seifritz, 1990). Methods to promote and enhance natural weathering have been proposed, e.g. studies by Schulling and Krijgsman (2006) and Renforth (2012). Reactions under the conditions at the earth's surface are relatively slow and the capacity for natural $\mathrm{CO}_{2}$ sequestration is limited, therefore a faster engineered process must be used to achieve a major impact. One proposed method, currently in the early stages of testing, involves the pumping of $\mathrm{CO}_{2}$-rich solutions down boreholes in to rock formations that contain silicate minerals with the requisite cations that are expected to undergo carbonation reactions. This is referred to as in situ CCSM and has been described by Kelemen and Matter (2009) and extensively studied by researches of CarbFix pilot project in Iceland (Gislason et al., 2010, Matter et al., 2009 and references therein).

The main CCSM method proposed, that has also seen the most research, is for feed materials, commonly silicates, to be processed in an industrial plant. This is referred to as ex situ mineralisation and involves significant thermo-chemo-mechanical pre-treatment of the resource material to strip out the cations and make them available for combination with $\mathrm{CO}_{2}$ to form carbonate minerals (Lackner et al., 1995). A range of methods have been proposed and tested at the lab scale (see Sanna et al., 2014a for review) involving single and multistage processes, aqueous and gas reactions. For an industrial process a throughput time of a few hours might be necessary. A process that has had substantial development and success involves acid leaching as a means of material pretreatment (Sanna et al., 2014b) and resources for this type of process are the main focus of this study.

The previous section showed that the largest concentrations of requisite cations (20-30wt\% $\mathrm{Mg}$ ) are present in the magnesium silicate minerals found in ultramafic rocks. The ultramafic rocks are defined by their abundance $(>90 \%$ ) of mafic (dark) minerals with high magnesium and concomitant low silica contents (Le Maitre et al., 2002). These rocks, composed almost entirely of mafic minerals, constitute the predominant resource for CCSM.

The main magnesium-rich silicate minerals contained within ultramafic rocks include:

- Olivine, commonly forsterite, chemical formula $\mathrm{Mg}_{2} \mathrm{SiO}_{4}$ (Mg content ca. 30\%).

- Orthopyroxene, commonly enstatite, chemical formula $\mathrm{MgSiO}_{3}$ ( $\mathrm{Mg}$ content ca. $21 \%$ ).

- Clinopyroxene, commonly diopside, chemical formula ( $\mathrm{Mg}, \mathrm{Ca}) \mathrm{SiO}_{3}$ ( $\mathrm{Mg}+\mathrm{Ca}$ content ca. $25 \%$ ).

- Serpentine group, commonly lizardite, chemical formula $\mathrm{Mg}_{3} \mathrm{Si}_{2} \mathrm{O}_{5}(\mathrm{OH})_{4}(\mathrm{Mg}$ content $25 \%)$ 
- Amphibole group, commonly tremolite, chemical formula $\mathrm{Ca}_{2}\left(\mathrm{Mg}, \mathrm{Fe}^{2+}\right)_{5} \mathrm{Si}_{8} \mathrm{O}_{22}(\mathrm{OH})_{2}(\mathrm{Mg}+\mathrm{Ca}$ content 25\%)

- $\quad$ Brucite, chemical formula $\mathrm{Mg}(\mathrm{OH})_{2}$ (Mg content $\left.42 \%\right)$

Although all ultramafic rocks contain a large proportion of magnesium silicate minerals, these minerals can occur in a wide variety of mineral combinations, not all of which may be suitable for CCSM. The original mineral assemblages that are characteristic of fresh, unaltered, ultramafic rocks, may be altered by geological processes during or subsequent to the rocks emplacement. This is most commonly associated with hydration of originally anhydrous minerals to form their hydrated equivalents and other phases. Degrees of hydration vary greatly and can reach as much as $100 \%$, forming new hydrous magnesium silicate minerals, such as serpentine and brucite from olivine or amphibole from pyroxene.

A range of laboratory experiments have been carried out to investigate the ease of liberation of cations from various rocks and minerals (O'Connor et al., 2005, Styles et al., 2014). The ease and efficiency of cation leaching (reactivity) define the suitability of a feed material for the CCSM process. Laboratory experiments have shown that olivine has good leaching properties but pyroxenes are poor. Their hydrated equivalents behave in a similar way and serpentine is generally good and amphibole poor. The exception is antigorite, a variety of serpentine that has poor leaching properties (Sanna et al., 2014b, Styles et al., 2014 and references therein). Consequently, rocks rich in pyroxene, amphibole and antigorite are not regarded as suitable feedstock material for an ex situ acid leach process (considered in this study) but could possibly be used if an alternative efficient $\mathrm{Mg}$ extraction process was identified. Brucite is a common, but normally only a very minor, constituent of serpentinites. However, as it is a hydroxide rather than a silicate, with a high $\mathrm{Mg}$ content and releases the cations very readily, its presence is beneficial to the overall leaching properties of the rock.

The carbonation reactions of olivine and serpentine are as follows:

Olivine (forsterite):

$$
\mathrm{Mg}_{2} \mathrm{SiO}_{4}+2 \mathrm{CO}_{2} \rightarrow 2 \mathrm{MgCO}_{3}+\mathrm{SiO}_{2}
$$

Serpentine (lizardite):

$$
\mathrm{Mg}_{3} \mathrm{Si}_{2} \mathrm{O}_{5}(\mathrm{OH})_{4}+3 \mathrm{CO}_{2} \rightarrow 3 \mathrm{MgCO}_{3}+2 \mathrm{SiO}_{2}+2 \mathrm{H}_{2} \mathrm{O}
$$

Although the carbonation reactions for both these magnesium-rich minerals are broadly similar, their different physical properties and structures mean that they might need to be treated separately. Some CCSM processes can be optimised for olivine or serpentine but are not often applicable to both (Styles et al., 2014). If olivine and serpentine occur in different rock types, in different areas they can easily be mined to extract a particular type and direct the products to a specific processing route. However, if they are present in the same rock, they are usually inter-grown on a fine $(<\mathrm{cm})$ scale making their separation uneconomic if not impossible. Therefore, the technological process either has to be able to cope with mixed mineral feed, or, if one component is not effectively utilised, the risk of reducing the overall efficiency of the process will be significantly increased.

Some rocks contain relatively high magnesium and calcium contents and occur abundantly in nature but are less suitable for ex situ CCSM processes. For example basalt, although abundant, does not 
contain as much magnesium and calcium as ultramafic rocks and is not as reactive in the ex situ acid leach processes that are currently being developed. Experiments by O'Connor et al., (2005) and Styles et al., (2014) show that the main constituent minerals, clinopyroxene $\left(\mathrm{CaMgSi}_{2} \mathrm{O}_{6}\right)$ and plagioclase feldspar $\left(\mathrm{CaAlSi}_{3} \mathrm{O}_{8}\right)$, are much less reactive than olivine and serpentine. This means that basalt is less suitable for an ex situ process where speed of reaction is essential. Slower reaction kinetics may be acceptable in an in situ situation such as that being investigated by the CarbFix project in Iceland.

Calcium silicates can potentially be used, however they are rare in nature and only occur in significant quantities in waste materials, such as recycled concrete and steel slags (Sanna et al., 2012 and references therein). The mineral wollastonite $\left(\mathrm{CaSiO}_{3}\right)$ has good reactivity ( $\mathrm{O}^{\prime}$ Connor et al., 2005) but only low tonnages are available and its prices can be as high as > US\$100 per tonne (Verta, 2013), as it is used for industrial processes, particularly in the production of ceramics. Consequently, on the basis of low abundance and high cost, wollastonite has not been considered as a potential resource in this study.

To constitute a resource a suitable feedstock material needs to contain a high proportion of minerals that are reactive in the CCSM process and be abundant. Future technological advances in chemical processing, changing economics of the process, allied to increases in the carbon price under carbon trading schemes means that CCSM may become comparable in cost to underground CCS. Development of in situ CCSM techniques may make it is possible that basaltic rocks or rocks high in feldspar may become more prospective CCSM resources in the future. Another implication for potential resources is that the in situ method can only be carried out at the location of the rock body and the $\mathrm{CO}_{2}$ must be taken to the disposal site, making co-location with $\mathrm{CO}_{2}$ emitters important. In contrast, the ex situ method could involve transport of $\mathrm{CO}_{2}$ or large volumes of rock to a suitable site. In this instance, co-location is less important but transport costs are a critical factor.

\section{Methodology for resource volume calculation}

\subsection{Outline}

The methodology used to calculate CCSM resources is similar to other large-scale resource reviews, for example MacDonald et al., 2012, in that resource quantity is calculated by a simple multiplication of estimated area and thickness and this figure appropriately modified using known properties of the rock types in question, estimated from analysis of published literature. On a global scale many assumptions must be made on the 'typical' properties of rock types, but as studies become smaller scale and more focused, better, more-locality specific data can be used and improve confidence in results generated.

\subsection{Types of ultramafic rocks}

Ultramafic rocks occur in a variety of geological settings and have different proportions of constituent minerals. These need to be considered separately when calculating resource volumes. Table 1 outlines the broad resource types and associated geological settings this study has used to quantify resources of CCSM feedstock materials.

In Table 1, Alaskan-type deposits are treated as a separate category. However, they have a restricted global distribution compared to the other ultramafic rock types and, in terms of CCSM feedstock 
resources, are broadly similar to ophiolites in some respects and layered igneous intrusions in others. Therefore, in the following analysis, Alaskan-type deposits are classified depending on which category they best match. For example, the Alaskan-type deposits of the Urals are considered as ophiolites due to their structure and high degree of alteration and Alaskan-type deposits in Alaska and British Columbia are considered as layered igneous intrusions due to their lower degree of alteration, dunite core, high levels of magmatic differentiation and association with platinum group minerals.

\subsection{Layered igneous intrusions}

The datasets used to define the resources in the layered igneous intrusions category consist of discrete points with an average spatial extent assigned to them. Point data are the best available information as no comprehensive dataset showing the spatial extent of individual layered igneous intrusions with global coverage exists in a readily available format.

Two datasets containing information on the global distribution of layered igneous intrusions were used and the results compared to validate the methodology. They were platinum group mineral (PGM) resources complied by Natural Resources Canada (NRCAN) (2012) and a dataset containing information on the global distribution of major deposits of PGMs compiled by the British Geological Survey (BGS) (published in Gunn, 2014). The presence of PGMs was used as a proxy for the location of layered igneous intrusions as they are the main location of PGM ore bodies. A similar approach was taken by Picot et al., (2011), in their study of worldwide potential for mineral carbonation, using existing PGM mines as locations for potential CCSM feedstock resources. However, this study only considered existing mine sites rather than total global resources. For both datasets only PGM occurrences that had associations with magmatic or lateritic deposits overlying magmatic deposits were selected thereby eliminating non-magmatic PGM occurrences with no potential for ultramafic rocks. These two datasets have significant differences. The NRCAN dataset is comprehensive and global. It contains 1040 records of magmatic- or laterite-associated PGM occurrences. The BGS database contains only 47 records of major PGM occurrences associated with magmatic deposits, many of which host established prospects or mines. Both datasets contain caveats related to their use. Whilst the Natural Resources Canada dataset is much more comprehensive than the BGS dataset it is not selective and so contains many occurrences linked to minor intrusions that may be too small or not contain significant quantities of ultramafic rocks to be suitable for CCSM feedstock material. The BGS dataset captures all the major layered igneous intrusions with large volumes of ultramafic rocks (up to $100000 \mathrm{~km}^{3}$ ) that are deemed the most prospective for CCSM. However, smaller-scale intrusions (less than $100 \mathrm{~km}^{3}$ ), which still may have resource potential, are not included. The distribution of these intrusions for the BGS and NRCAN datasets is shown on Figure 3.

\subsubsection{Assumptions required for resource volume calculation}

For volume calculation the spatial extent of layered igneous intrusions needs to be estimated from the point information in the databases. Two figures for the 'typical' size of a layered igneous intrusion were estimated, one for the BGS dataset and one for the NRCAN dataset. For the NRCAN dataset, a figure of $100 \mathrm{~km}^{2}$ was used for areal extent. This was based on the areal extent of the Skaergaard layered igneous complex, which is $100 \mathrm{~km}^{2}$ (McBirney, 1996). For the BGS dataset, an average figure of $2000 \mathrm{~km}^{2}$ was taken to represent the much larger intrusions included in this dataset, for example Muskox, Great Dyke, Rincón del Tigre and Stillwater, which all have areas between 1000 and $3000 \mathrm{~km}^{2}$ (Table 2). 
Not all rocks within these layered igneous intrusions will be suitable as a feedstock material for CCSM as they do not comprise $100 \%$ ultramafic rocks and not all ultramafic minerals are equally reactive during the CCSM processes. Based on information about both the surface outcrop and the internal stratigraphy of some typical major intrusions, it was assumed that $15 \%$ of a layered intrusion may be a suitable resource. This figure was derived by the review of well-studied intrusions (sources are listed in Table 2). The key information used is collated in Table 2 and a comparison of the internal stratigraphy of selected major intrusions is shown in Figure 2.

Although a figure of $15 \%$ was considered representative, these deposits are varied in nature with the range encompassing the Great Dyke, Zimbabwe, that has a surface outcrop consisting of $70-80 \%$ ultramafic rocks (Wilson, 1996) to the Bushveld Complex, one of the largest layered igneous intrusions in the world, having a surface outcrop with less than $10 \%$ ultramafic rocks (Cawthorn et al., 2002).

It was assumed, based on the type sections, that the ultramafic rocks within layered igneous intrusions are forsteritic olivine peridotites and harzburgites with a low degree of serpentinisation. Where information has been available (generally the larger intrusions) ultramafic rocks that are not suitable for CCSM feedstock materials, such as orthopyroxenite and clinopyroxenite (due to the low olivine content and lower leachablity of pyroxene), have been discounted. Many layered igneous intrusions have been serpentinised to some degree. However, this is difficult to estimate on a global scale. Typically, the large layered igneous intrusions are mostly unaltered and smaller intrusions are more susceptible to alteration as the peripheral alteration envelope will be proportionately larger relative to the total mass of the intrusion. Little alteration is recorded at major intrusions such as Stillwater, Duluth and the Bushveld Complex (McCallum, 1996; Miller and Ripley, 1996 Eales and Cawthorn, 1996). Serpentinisation is commonest at the boundaries of intrusions and along fault and shear zones, where fluids have circulated. For example, dunite from the Great Dyke, Zimbabwe is $100 \%$ serpentinised at the surface but the degree of serpentinisation decreases significantly with depth (Wilson, 1996) or the Twin Sisters Dunite, USA, which has a serpentinised zone up to $700 \mathrm{~m}$ thick around an unaltered dunite core (Ragan, 1967). As a result serpentinisation is deemed to be insignificant at depth in the majority of layered igneous intrusions and, therefore, for calculation purposes all rocks are considered as unaltered.

The mass of ultramafic rocks contained within layered igneous intrusions was calculated based on the densities of the most common constituent ultramafic rock types, such as peridotite and pyroxenite, a density of $3.2 \mathrm{~g} / \mathrm{cm}^{3}$ was used.

\subsection{Ophiolites}

Ophiolites are fragments of former ocean crust that have been obducted during the collision of tectonic plates. They consist of an upper part composed of crustal mafic rocks and a lower part of mantle derived ultramafic rocks that can be several kilometres in thickness. The global extent of ophiolites is shown in Figure 4, which was compiled from Asch (2005), Krevor et al., (2009), Voormeij and Simandl (2004) and Exxon Production Research Company and The American Association of Petroleum Geologists (1985) (Table 3).

Ophiolites occur in a variety of different settings, which in turn can affect their potential for CCSM feedstock material. Therefore, different assumptions have been made for European and Asian Tethyan ophiolites, ophiolites from the rest of the World and ophiolitic rocks of the Urals. 
Characteristics of ophiolites from these settings have been compiled in Table 4, and used to make assumptions regarding typical attributes.

\subsubsection{Assumptions required for resource volume calculation}

Where possible, only the ultramafic component of ophiolites has been included in the calculation. However, this refinement was not always possible due the resolution of some data sets and the complexity of tectonic settings in which ophiolite complexes are found. As a result assumptions have been made regarding the proportion of the ultramafic component. For Tethyan ophiolites, a value of $45 \%$ was used to represent the volume percent of the proportion of ultramafic rocks, taken from the average composition for type sections (Coleman 1971, Robinson et al., 2003, Dilek and Furnes 2009, Hawkins 2003).

For USA and British Columbian ophiolites, a value of $50 \%$ was used, as the proportions of mantle to crustal rocks are generally higher (Table 4). Some Alaskan-type intrusions (e.g. those of the Urals), although technically not ophiolites, have been considered in this category as they occur in similar tectonic settings. For ophiolites of the rest of the world a value of $40 \%$ was used based on the average composition of representative sections (Coleman 1971, Hawkins 2003, Komor et al., 1985, Ulrich et al., 2010 and Hopson et al., 2008) (Table 4).

For ophiolites, it was assumed that all ultramafic rocks could constitute a feedstock for CCSM processes as the proportion of unreactive pyroxene-rich rocks is generally low. Therefore these figures represent maximum values as any dilution due to the presence of other minerals (e.g. pyroxene, amphibole and feldspar) has not been factored in. Quantitative data about the proportions of rock types is generally not available on a global scale.

This study has attempted to calculate an average degree of serpentinisation for ophiolite rocks, despite the problems due to their diverse and varied nature. Across the global spectrum of ophiolite compositions the degree of serpentinisation can range from 0 to 100\%. For European Tethyan ophiolites a value of $50 \%$ has been taken based on reported values from typical ophiolites (Coleman 1971, Robinson 2003, Dilek and Furnes 2009 and Hawkins 2003) (Table 4). The same value has been used for rest of the world ophiolites. This most likely represents a minimum value. A value of $80 \%$ is used for ophiolites of the USA and British Columbia, based on Table 4, as these ophiolites are generally older and more altered than Tethyan ophiolites. No attempt has been made to calculate the degree of serpentinisation for the ultramafic rocks of the Urals as serpentinisation is not thought to be significant for these large dunite bodies (Zohan, 2002).

There are three common members of the serpentine mineral group: lizardite, chrysotile and antigorite and they have different properties with regards to CCSM processes. The type of serpentine will depend largely on the temperature of formation. Lizardite and chrysotile were formed at lower temperatures, have similar properties, and are the most suitable for CCSM feedstock material. They are particularly associated with the younger ophiolites that have been subjected to fewer metamorphic events, possibly only the emplacement event, and cooler conditions, for example ophiolites of Oman-UAE, New Caledonia and Papua (Nicolas and Boudier, 2003) or European Tethyan ophiolites (Onen, 2003). The serpentine type antigorite is much less reactive (Sanna et al. 2014b, Styles et al.,2014) and less suitable for CCSM. However, antigorite, formed at higher temperatures, is only reported from the small number of ophiolites that have been 
affected by moderate grade regional metamorphism, often subsequent to obduction. An example is the ophiolites of Vermont which, although heavily serpentinised, have undergone regional metamorphism and contain only antigorite (Jahns, 1967). However, as few publications contain information about the proportions of the specific type of serpentine present, all serpentine is assumed to be lizardite and therefore suitable. All calculations therefore represent the maximum figure.

The density of a pure serpentine rock is $2.6 \mathrm{~g} / \mathrm{cm}^{3}$, while the density for unaltered ultramafic rocks is $3.2 \mathrm{~g} / \mathrm{cm}^{3}$ as per assumptions made for layered igneous intrusions. The average density for partially serpentinised rocks was taken to be $2.9 \mathrm{~g} / \mathrm{cm}^{3}$ based on the most common mineral assemblages that are a mixture of fresh minerals and serpentine with around $50 \%$ serpentine.

\subsection{Archaean Greenstone Belts}

Ultramafic rocks also occur within Archaean metamorphic terrains, these are remnants of ancient crustal rocks (older than 2.5 billion years). The ultramafic component of these rocks includes metamorphosed igneous intrusions, but the most common and most prospective for CCSM feedstock resources is komatiites, which are ultramafic lavas. The CGMW Geological Map of the World (Commission for the Geological Map of the World - CGMW, 2000) delineates terrains of Archaean plutonic, metamorphic and extrusive rocks, some of which are ultramafic (Figure 5). Only Archaean rocks have been used for the purposes of this study. However, Paleoproterozoic greenstone belts containing ultramafic rocks, such as those of the Fennoscandinavian shield or the Flin-Flon Greenstone Belt, Canada, could also be a prospective resource for CCSM feedstock material.

Only a small percentage of the Archaean terrains depicted on the CGMW Geological Map of the World (2000) comprise rocks of ultramafic composition that may be suitable as CCSM feedstock material. The percentage of suitable CCSM resources has been derived by a comparison of the areas covered by the Geological Map of the World with Archaean greenstone belts prospective for CCSM feedstock material derived from more detailed mapping (Geological Survey of India, 1993). This showed that of the areas of exposed Archaean rocks, only $20 \%$ comprise greenstone belts or metavolcanosedimentary belts, and of this only $10 \%$ is likely to be ultramafic rocks (Table 6). As a result a value of $2 \%$ has been used to represent the quantity of ultramafic rocks within these Archaean terrains.

The majority of ultramafic Archaean rocks have been altered by metamorphic processes which can significantly affect the types of Mg-rich minerals present. The alteration minerals depend on the temperature of metamorphism and original composition of the source rocks (Blais and Auvray, 1990). For low temperature alteration the end product is largely dependent on the MgO content of the rock.

The range of $\mathrm{MgO}$ contents found in most komatiite deposits is $25-35 \%$ (Table 5), so it can be assumed that low temperature metamorphism (typically greenschist facies) will lead to serpentinisation. Higher temperature metamorphism will alter ultramafic minerals to amphiboles (Stiegler et al., 2010), which are of little use in CCSM due to their resistance to the release of $\mathrm{Mg}$ during processing. Based on information in Table 7 and examples of well-known komatiites a value of $50 \%$ has been used to represent the proportion of ultramafic minerals altered to serpentine 
minerals suitable for CCSM feedstock material. This figure is based on approximately $30 \%$ of deposits being metamorphosed amphibolites and of the remaining $70 \%$, around $20 \%$ are altered to antigorite or other minerals which are not suitable for the CCSM process. Table 7 gives the range of serpentinisation in komatiites, which has been used to derive the percentage of komatiite that has been serpentinised. Resources of ultramafic rock not metamorphosed to lizardite serpentine have not been incorporated in the calculation as these are unlikely to be a resource for CCSM feedstock material; these resources are also not significant in size.

\subsection{CCSM resource thickness}

Many of the resources described above have considerable thicknesses, well in excess of that feasible to economically extract low-value bulk resources. For the purpose of this study a thickness of $100 \mathrm{~m}$ has been used for resource estimates, a typical depth of a medium-sized hard-rock quarry. This is a conservative estimate and very large bodies of rock may be able to accommodate large open pits with much greater working depths. Estimates of resources by researchers in other countries have used depths of up to $500 \mathrm{~m}$ (Lackner et al., 2008). These maximum depths are further complicated if the ultramafic rocks are located in an existing mine site (for example many nickel deposits contained within layered igneous intrusions). In these cases the maximum depth of working will be greatly increased and constrained by the economics of the higher value commodity being worked. As a result, for more focused studies looking at CCSM resources in existing mine sites, much greater depths may be appropriate.

\section{Results of global resource calculations}

Taking into account all the assumptions, caveats and discussions made previously, the values for the global resources of CCSM feedstock material from ultramafic rocks are presented in Table 8 to Table 11. Table 8, which provides details regarding the calculation of tonnage of CCSM feedstock from layered igneous intrusions, shows that both the BGS and NRCAN data gives similar values and boosts confidence in the assumptions made for each dataset. For the final totals the more conservative BGS data was used. Table 9 presents the detail regarding the calculation of tonnage of CCSM feedstock material derived from ophiolite rocks, giving a breakdown of ophiolite resources within different areas. Table 10 shows the calculation of tonnage of CCSM feedstock material from Archaean greenstone belts. The tables show estimated resources for serpentinised and fresh rocks separately to give an indication of possible resources if they were used in a process that could only utilise one type. If this were the case, the caveat discussed previously, that often these may not be in separate rock bodies, it must be borne in mind and that the resource might be substantially less. A summary of the results is shown in Table 11.

\section{Confidence in global resources calculations}

This study has made a number of assumptions to calculate global volumes of ultramafic rocks. One of the most important of these is that the volumes are based on the surface mapping, at a global or regional scale, for both ophiolites and Archaean ultramafic rocks. The assumption made for the area of layered igneous intrusions was that they were associated with PGM mineralisation, however this would disregard intrusions that are barren for PGM. Therefore the estimate should be regarded as a minimum. Volumes for layered igneous intrusions are based on average size of intrusions, but these can be made with some confidence, as similar results are obtained from two separate datasets with 
different assumptions applied. All volumes were calculated using a conservative thickness of $100 \mathrm{~m}$, this can be considered as shallow compared to the deep profiles of many of the types of deposit, particularly the ophiolites and the depth of many modern open-pit mines. The assumption is made that lithologies mapped and properties recorded at the surface are representative of those at depth. However, confidence in this assumption would decrease with depth.

The final tonnages depend substantially upon assumptions made on the proportion of CCSM feedstock materials from ultramafic rocks within the mapped or assumed extents of layered igneous intrusions, ophiolitic rocks and Archaean rocks. The geological settings of these resource types are all extremely varied, when considered on a global scale. The approach taken was to consider classic well documented examples and use average values from these. Layered igneous intrusions are the most variable with the amount of ultramafic rocks present in the case studies varying between $20 \%$ and $70 \%$ (Table 2). This is further complicated by the presence of rocks, such as pyroxenites, that do not constitute a CCSM feedstock resource (by most processes considered) but can form a significant proportion of some intrusions. Hence, a conservative estimate of only $15 \%$ was used for the proportion of suitable resources which is likely to represent a minimum value. The same principle of a minimum value is also applied to the figure of only $2 \%$ used for the Archaean rocks calculation. In contrast, the assumption that $40-50 \%$ of ophiolite deposits could be used for CCSM feedstock resources (depending on the type of ophiolite) potentially leads to an over estimation of resource volumes as areas defined as ophiolite rocks may contain non-ultramafic rocks. This figure could be more accurate and probably decrease if further work identified unsuitable ultramafic rocks from within the datasets used to define ophiolite resources.

There are also mineralogical and geological unknowns which may render ultramafic rocks within the areas defined as unsuitable for CCSM feedstock material. For example variations in mineralogy with depth and local impurities may make the rock unsuitable. Without detailed geological, geochemical and mineralogical analyses these are impossible to identify. It is beyond the scope of this global scale study to consider these factors. Regional scale studies are more suited to this level of detail, an example of which has been undertaken for India by Mani et al., (2008).

\section{Application: A case study for south and eastern Europe}

Regional case studies are useful in demonstrating how data from resources assessments such as this might be used to indicate the locations where CCSM could practically be applied. Southern and Eastern Europe is one such example; the Tethyan ophiolite belt runs through Croatia, Bosnia Herzegovina, Serbia, Montenegro, Albania, Macedonia and Greece. These countries have little access to geological $\mathrm{CO}_{2}$ storage and are largely reliant on coal fired power stations, often fuelled by high $\mathrm{CO}_{2}$ emitting brown coal. The large quantity of ultramafic rocks, lack of alternative storage options and number of significant point source $\mathrm{CO}_{2}$ emitters means there is potential for CCSM in this region.

Data from the International Energy Agency's (IEA) 2006 global emissions database (IEA 2006) show that although these countries are not large emitters on a global scale, they contain numerous small to medium point source emitters and combined they contribute $0.5 \%$ of the world's $\mathrm{CO}_{2}$ emissions and $1.3 \%$ of Europe's. These are in the form of smelters, cement works and power stations, all of which would be suited for CCSM processes. 
Ultramafic rocks of the Tethyan ophiolite belt are the source of all CCSM feedstock material in these countries. Mafic and ultramafic rocks, as defined by Asch (2005), cover large surface areas, especially in Serbia and Albania, which are all considered prospective for CCSM feedstock material. Albania alone is estimated to contain 280,000 million tonnes of serpentinised rocks and 310,000 million tonnes of olivine rich rocks based on the criteria used to calculate global resources.

These resources can be linked to individual point source emitters. Figure 6 shows a number of point source $\mathrm{CO}_{2}$ emitters in close proximity, or sited on top of, ultramafic rocks. The largest of these being coal fired power stations in Serbia and Greece. Based on the IEA's global emissions database (IEA 2006) there are also numerous small power stations, cement works and refineries with access to ultramafic rocks, all of which may be suited to a CCSM process. It can be seen in Figure 6 that around $75 \%$ of $\mathrm{CO}_{2}$ point source emitters are within $60 \mathrm{~km}$ of a potential CCSM feedstock resource $(60 \mathrm{~km}$ being the maximum transport distance for bulk commodities, as explained in the discussion). Three sites lie directly on ultramafic rocks; two small power stations in Bosnia Herzegovina, both emitting around 7,000 thousand tonnes of $\mathrm{CO}_{2}$ per year, and a refinery in central Serbia with undisclosed $\mathrm{CO}_{2}$ emissions.

\section{Discussion}

The estimates made here show that potentially 90 teratonnes of material suitable for CCSM feedstock material may be present globally if the process can deal with mixtures of different minerals. Studies of the process of CCSM estimate that between 1.6 and 3.7 tonnes of feedstock material are required to capture 1 tonne of $\mathrm{CO}_{2}$ (Lackner et al., 1995, IPCC 2005). Using estimates from the Global Carbon Project (2012) for annual global $\mathrm{CO}_{2}$ emissions (for 2011, 34.7 billion tonnes of emissions came from power generation from fossil fuels and cement manufacture), this study shows that there are potential resources of CCSM feedstock material to capture global $\mathrm{CO}_{2}$ emissions for between 700 and 1,600 years based on the current rate of global $\mathrm{CO}_{2}$ emissions.

The figure of 90 teratonnes is the total available resource based only on geological factors and extraction to $100 \mathrm{~m}$ depth. If operational, economic and environmental considerations are factored in the figure will be much lower. However, it demonstrates that there are sufficient resources of CCSM feedstock material for CCSM to be considered as an option that could make a significant impact on global $\mathrm{CO}_{2}$ levels, if an economically acceptable technology for processing can be developed. Any development would also need to be coupled with an incentive to utilise the technology in the form of a regulatory framework for controlling emissions.

Implementation of CCSM on a large scale would entail the mining, processing and transport of vast amounts of material. Industries that deal with large volumes of material are already well established, such as those for coal and iron ore, showing that the technology and infrastructure exists with acceptable economic constraints. A comparison can be made with the coal industry, this is, by tonnage, one of the largest mineral industries globally and produced nearly 8 billion tonnes of coal in 2011 (British Geological Survey 2013). Global reserves are around 860 billion tonnes (BP 2013). No resource estimates are available for recent years but would be an order of magnitude larger than this. If the global coal industry were to be compared to CCSM resources, an industry producing 8 billion tonnes of ultramafic material could capture between 5 and $15 \%$ of emissions from fossil fuel power generation and cement manufacture. Resources of 90 teratonnes has potential to sustain an 
industry at least an order of magnitude larger than the global coal industry, however the environmental and economic constraints of developing such an industry would be substantial.

The environmental constraints of developing an industry based on the construction of new mines to extract CCSM feedstock material would be a considerable. The substantial size of pit required coupled with the necessary infrastructure and associated heavy industry could have a significant effect on the local environment, including visual impact, noise, dust and loss of habitat. The carbonation process will use considerable amounts of water and other chemical reagents that will have consequences for both water supply and industrial waste disposal. If the process reaches a pilot scale, the use of tailings of ultramafic rocks from existing mine sites could minimise many of these hurdles as much of the environmental mitigation measures and permitting will already be in place.

An example of the possible implementation on a local scale uses the case study of southern Europe used earlier. The largest emitter in this example is a coal burning power station which emits 9 million tonnes of $\mathrm{CO}_{2}$ per year. This means that between 14 million and 30 million tonnes of ultramafic material would be required every year to sequester this $\mathrm{CO}_{2}$. A quarry $100 \mathrm{~m}$ deep and with a surface area of $1 \mathrm{~km}^{2}$ would supply CCSM feedstock for 10 years. This demand could be met from ophiolitic ultramafic rocks $15 \mathrm{~km}$ south of the site, however the requirement of a mine of this magnitude would have planning and environmental constraints.

It is also important to note that, due to the low value, high volume nature of these materials, the resources would either have to be in close proximity to the emitter or have access to transport by ship to be a viable process. Moving the huge amounts of material any distance is only feasible by ship. This would require similar methods to those currently used for bulk commodities that are transported on a global scale such as coal and iron ore. As a result many remote inland ultramafic rock deposits, such as those in Northern Canada or central Africa are unlikely to be exploited for CCSM. These resources may be much better utilised in regions distant from geological carbon storage options or for small scale emitters that can be sited near CCSM resources. For areas such as these the information displayed in this study allows planners and policy makers to consider the viability of CCSM and highlights the possible future option of this method of carbon capture.

Calculation of the maximum distance for which it would be economic or feasible to transport this material is beyond the scope of this study. However, a study by Moosdorf et al., 2014, has calculated efficiency in terms of $\mathrm{CO}_{2}$ emissions of transportation of CCSM feedstock material. This study calculated transportation would only account for $0.3-0.5 \%$ of the potentiality sequestered $\mathrm{CO}_{2} \mathrm{so}$, in terms of carbon budgets, transportation is not an issue. For major projects, if rail or ships were used, transport distances could be considerable whilst transportation by road might only be possible over much shorter distances. Consideration of transport distances would not be such an economic impediment if pipelines were used to transport the waste $\mathrm{CO}_{2}$ from the emission source to the CCSM feedstock material source. This would also facilitate disposal of waste products which can be used to backfill voids left by mineral extraction. The maximum distance low value, bulk materials can be hauled by road is $60 \mathrm{~km}$ before transportation and fuel costs become prohibitive (Highley et al., 2004). These distances may be extended however if the value of the material were to be increased, for example by the introduction of a carbon emissions trading scheme. If transported by rail, or by a pipeline infrastructure, distances up to $200 \mathrm{~km}$ may be feasible (Highley et al., 2004). The 
combination of both rock resources and emitters at coastal locations could enable the process to be undertaken anywhere in the world, as the main component of sea transport is handling charges for loading and unloading while fuel for the journey is relatively minor.

CCSM technology is still at the laboratory development stage and it is possible that the first step towards implementation would be in niche markets where there are particularly favourable factors. Readily available resources are likely to be present in the form of waste dumps from metallic mineral operations and asbestos mines hosted in ultramafic rocks, as this material has already been crushed and is accessible at the surface ready for further processing. For example Mt Keith, a nickel mine in Australia produces 11 million tonnes of serpentinite waste per year (Wilson et al., 2009). The Hitura nickel mine in Finland has 6 million tonnes of serpentinite stored in stockpiles and this waste has been used as a source for studies into CCSM processes (Zevenhoven et al., 2011, Teir et al., 2007). Examples such as these might be the most suitable locations for pilot studies or plants and if this technology were to be fully developed these mine sites would seem the most obvious locations for the installation of large scale infrastructure for industrial CCSM. Active mine sites are typically large $\mathrm{CO}_{2}$ emitters and carbon emissions trading schemes such as are being implemented in the EU and North America could make an industrial scale CCSM process economic.

It is also possible that the production of CCSM feedstock material as a by-product could make associated nickel and PGE deposits more economically feasible, if the regulatory framework on $\mathrm{CO}_{2}$ emissions was such that a carbon price benefit could be factored in. Studies into the Turnagain nickel deposit in British Columbia have concluded that substantial savings could be made if a CCSM plant was built on site, making this prospect economically viable to mine, based on a carbon capand-trade scheme with a carbon price of $\$ 200$ per tonne (Hitch and Dipple, 2012). The introduction of carbon pricing would also mean the construction of mineral carbonation plants at point source emitters may become economically feasible.

To plan for the most efficient use of non-renewable mineral resources, the size, quality and location of those resources must be known. Having spatial information for CCSM ultramafic feedstock resources as well as the locations of major $\mathrm{CO}_{2}$ emitters within a GIS allows for further analyses linking emitters to resources. The International Energy Agency's 2006 global emissions database (IEA 2006) contains information on industrial point source $\mathrm{CO}_{2}$ emitters globally. Quantifying and showing the spatial distribution of CCSM resources in this way is vital for effective planning and policy development for future carbon capture and storage.

This analysis, based on the IEA's emitters, shows that $30 \%$ of ultramafic rocks with potential for CCSM feedstock are within $60 \mathrm{~km}$ of a recorded $\mathrm{CO}_{2}$ emission point source $(40 \%$ if $100 \mathrm{~km}$ transport distance was used). This relatively low figure is not surprising as the locations of most Archaean greenstone belts are continental interiors and ophiolite rocks are commonly in mountainous regions, neither of which are typically the densely populated, industrialised areas where $\mathrm{CO}_{2}$ emitters are located. However, taking this into account, even if the total resource figure was reduced by $70 \%$ to represent those resources in close proximity to emitters, substantial resources remain, with the potential to capture global emissions for 200 years.

The greatest challenge to CCSM technology is to develop a commercially viable process and deal with the large quantities of carbonate and amorphous silica products (which in themselves may be a secondary resource). 


\section{Conclusion}

This study is a first attempt to calculate an approximate global figure for ultramafic rocks that could be used as resources for CCSM. These figures provide information required to effectively plan for the use of these minerals. It shows that resources of CCSM feedstock material from both serpentinised and unserpentinised rocks are abundant and that the availability of resources is not a constraint on the development of CCSM, which could provide a way to significantly reduce anthropogenic $\mathrm{CO}_{2}$ emissions, if commercially acceptable processes were to be developed. Although this study gives a generalised review of the abundance of specific rock types on a global scale, and as such many assumptions have been made, the results most likely represent values from the lower end of the possible available resource and are backed up by comparison with major known examples. The possible resource figure of 90 teratonnes is huge and could make a substantial impact on global emissions, if the technology can be made viable, as this could capture global emissions for hundreds of years. Using this method to capture a major proportion of global emissions would require a mining industry on a scale very much larger than anything known at present and very large open pit mines in areas where such industry had not previously existed and might be deemed unacceptable. However even if only $1 \%$ of resources were used, which is enough to capture global $\mathrm{CO}_{2}$ emissions at current rates for over 7 years, in areas where there is an appropriate niche that makes it attractive, a significant impact on global and particularly local emissions could be made. Therefore as resources are not a constraint CCSM can be considered as an alternative method of carbon capture in those areas where geological storage is not possible and even as a viable equivalent in all areas if comparable cost is achieved. 


\section{Acknowledgment}

We thank the Energy Technologies Institute (ETI) that commissioned and funded the work as part of its CCS programme. Peter Pitfield, Teresa Brown, Alicja Lacinska and the reviewers of Applied Earth Science are thanked for their valuable contributions and review. This paper is published with permission of the Executive Director of the British Geological Survey (NERC)

\section{Tables}

\begin{tabular}{|c|c|c|c|}
\hline Resource type & Geological setting & Typical ultramafic rock types & Examples \\
\hline Ophiolites & $\begin{array}{l}\text { Areas where a section } \\
\text { of the oceanic crust } \\
\text { has been thrust onto } \\
\text { continental crust }\end{array}$ & $\begin{array}{l}\text { The lower tectonised part contains } \\
\text { harzburgite and lherzolite, hosting } \\
\text { pods of dunite. Cumulate part } \\
\text { contains layers of dunite. } \\
\text { Serpentinites are common. }\end{array}$ & $\begin{array}{l}\text { Troodos, Cyprus; } \\
\text { Semail, Oman/UAE; } \\
\text { Bay of Islands, } \\
\text { Newfoundland, } \\
\text { Canada }\end{array}$ \\
\hline $\begin{array}{l}\text { Layered igneous } \\
\text { intrusions }\end{array}$ & $\begin{array}{l}\text { Large intrusions } \\
\text { formed under or in } \\
\text { continental crust }\end{array}$ & $\begin{array}{l}\text { Layers of peridotite and } \\
\text { pyroxenite can extend laterally } \\
\text { over the whole intrusion. } \\
\text { Serpentinisation is variable with } \\
\text { alteration being concentrated } \\
\text { along faults and shear zones. } \\
\text { Ultramafic layers occur, but mafic } \\
\text { layers tend to predominate. }\end{array}$ & $\begin{array}{l}\text { Bushveld, South } \\
\text { Africa; Great Dyke, } \\
\text { Zimbabwe; Duluth, } \\
\text { Canada; Stillwater, } \\
\text { Montana, USA }\end{array}$ \\
\hline Greenstone belts & $\begin{array}{l}\text { Differentiated flows } \\
\text { and sub-volcanic } \\
\text { intrusions in Archaean } \\
\text { mafic volcanic } \\
\text { complexes }\end{array}$ & $\begin{array}{l}\text { The basal parts of lava flows and } \\
\text { sills are generally peridotitic. } \\
\text { Degree of serpentinisation is } \\
\text { variable, but generally high. }\end{array}$ & $\begin{array}{l}\text { Central Lapland } \\
\text { Greenstone Belt, } \\
\text { Finland; Kambalda } \\
\text { Greenstone Belt, } \\
\text { Australia }\end{array}$ \\
\hline $\begin{array}{l}\text { Alaskan-type } \\
\text { volcanic arc } \\
\text { plutons }\end{array}$ & $\begin{array}{l}\text { Intrusive magmatic } \\
\text { rocks intruded in } \\
\text { volcanic arcs in a } \\
\text { subduction setting }\end{array}$ & $\begin{array}{l}\text { A core of unaltered dunite } \\
\text { surrounded by concentric zones of } \\
\text { pyroxene-rich rocks, such as } \\
\text { wehrlite and clinopyroxenite, with } \\
\text { variable degrees of alteration. }\end{array}$ & $\begin{array}{l}\text { Urals, Russia; Duke } \\
\text { Island, Alaska, USA } \\
\text { and Turnagain, } \\
\text { British Columbia, } \\
\text { Canada }\end{array}$ \\
\hline
\end{tabular}

Table 1. Ultramafic rock associations considered by this study (modified from Voormeij and Simandl 2004)

\begin{tabular}{|c|c|c|c|c|c|}
\hline Name & $\begin{array}{l}\text { Area } \\
\left(\mathrm{km}^{2}\right)\end{array}$ & $\begin{array}{l}\text { Total thickness } \\
\text { (m) }\end{array}$ & $\begin{array}{l}\text { Thickness of } \\
\text { ultramafic rocks (m) }\end{array}$ & $\begin{array}{l}\text { Types of ultramafic } \\
\text { rocks }\end{array}$ & Source \\
\hline $\begin{array}{l}\text { Rincón del } \\
\text { Tigre }\end{array}$ & 3000 & 4600 & 2600 & $\begin{array}{l}\text { Mainly dunite with } \\
\text { bands of harzburgite } \\
\text { and orthopyroxenite }\end{array}$ & $\begin{array}{l}\text { Annells, 1986a and } \\
\text { 1986b; Prendergast, } \\
2000\end{array}$ \\
\hline Stillwater & 1170 & 6500 & 1300 & $\begin{array}{l}\text { Peridotite }(700 \mathrm{~m}) \\
\text { orthopyroxenite } \\
(370 \mathrm{~m})\end{array}$ & $\begin{array}{l}\text { McCallum, 1996; } \\
\text { Zientek et al., } 2002\end{array}$ \\
\hline Muskox & 1670 & 2200 & 1500 & $\begin{array}{l}\text { Dunite, pyroxenite } \\
\text { and peridotite }\end{array}$ & $\begin{array}{l}\text { Irvine and Smith, } \\
1967\end{array}$ \\
\hline Skaergaard & 100 & 3500 & 1200 & Olivine cumulates & McBirney 1996 \\
\hline $\begin{array}{l}\text { Bushveld } \\
\text { (Rustenburg }\end{array}$ & 65000 & $7000-9000$ & $1600-2100$ & $\begin{array}{l}\text { Harzburgite, dunite } \\
\text { (around } 800 \mathrm{~m} \text { ) } \\
\text { Pyroxenite (around }\end{array}$ & $\begin{array}{l}\text { Eales and Cawthorn, } \\
\text { 1996; Cawthorn et }\end{array}$ \\
\hline
\end{tabular}




\begin{tabular}{|c|c|c|c|c|c|}
\hline \multicolumn{4}{|l|}{ Layered Suite) } & \multirow{2}{*}{$\begin{array}{l}1500 \mathrm{~m}) \\
\text { Olivine cumulates }\end{array}$} & \multirow{2}{*}{$\begin{array}{l}\text { al., } 2002 . \\
\text { Miller and Ripley, } \\
\text { 1996; Miller, } 2011\end{array}$} \\
\hline Duluth & 5000 & 4000 & Not specified & & \\
\hline Great Dyke & 3300 & 3000 & 2000 & $\begin{array}{l}\text { Dunite (often } \\
\text { serpentinised) }(900 \mathrm{~m}) \\
\text { Pyroxenite } 1100 \mathrm{~m})\end{array}$ & $\begin{array}{l}\text { Wilson, 1996; } \\
\text { Oberthür, } 2002\end{array}$ \\
\hline Munni Munni & 112 & 4450 & 1850 & $\begin{array}{l}\text { Dunite, wehrlite and } \\
\text { pyroxenite }\end{array}$ & $\begin{array}{l}\text { Barnes et al., 1990; } \\
\text { Barnes and Hoatson, } \\
1994\end{array}$ \\
\hline
\end{tabular}

Table 2. Compilation of the characteristics of selected layered igneous intrusions in relation to CCSM feedstock materials.

\begin{tabular}{|c|c|c|}
\hline Source & Name of dataset & Use \\
\hline Asch, 2005 & $\begin{array}{l}\text { The 1:5 million International } \\
\text { Geological Map of Europe and } \\
\text { Adjacent Areas }\end{array}$ & $\begin{array}{l}\text { Used to define the locations and } \\
\text { extent of ultramafic rocks within } \\
\text { ophiolites in Europe and the } \\
\text { Middle East }\end{array}$ \\
\hline Krevor et al., 2009 & Ultramafic resources of the USA & $\begin{array}{l}\text { Used to define the locations and } \\
\text { extent of ultramafic rocks within } \\
\text { ophiolites within the USA }\end{array}$ \\
\hline Voormeij and Simandl 2004 & $\begin{array}{l}\text { Ultramafic resources of British } \\
\text { Columbia }\end{array}$ & $\begin{array}{l}\text { Used to define the locations and } \\
\text { extent of ultramafic rocks within } \\
\text { ophiolites within British Columbia }\end{array}$ \\
\hline Exxon Production Research & Tectonic map of the World & Used to define the locations and \\
\hline Company and The American & 1:10000000 & extent of ophiolitic rocks for areas \\
\hline Association of Petroleum & & not covered by more detailed \\
\hline Geologists 1985 & & regional studies \\
\hline
\end{tabular}

Table 3. Sources used for the spatial definition of ophiolitic resources 


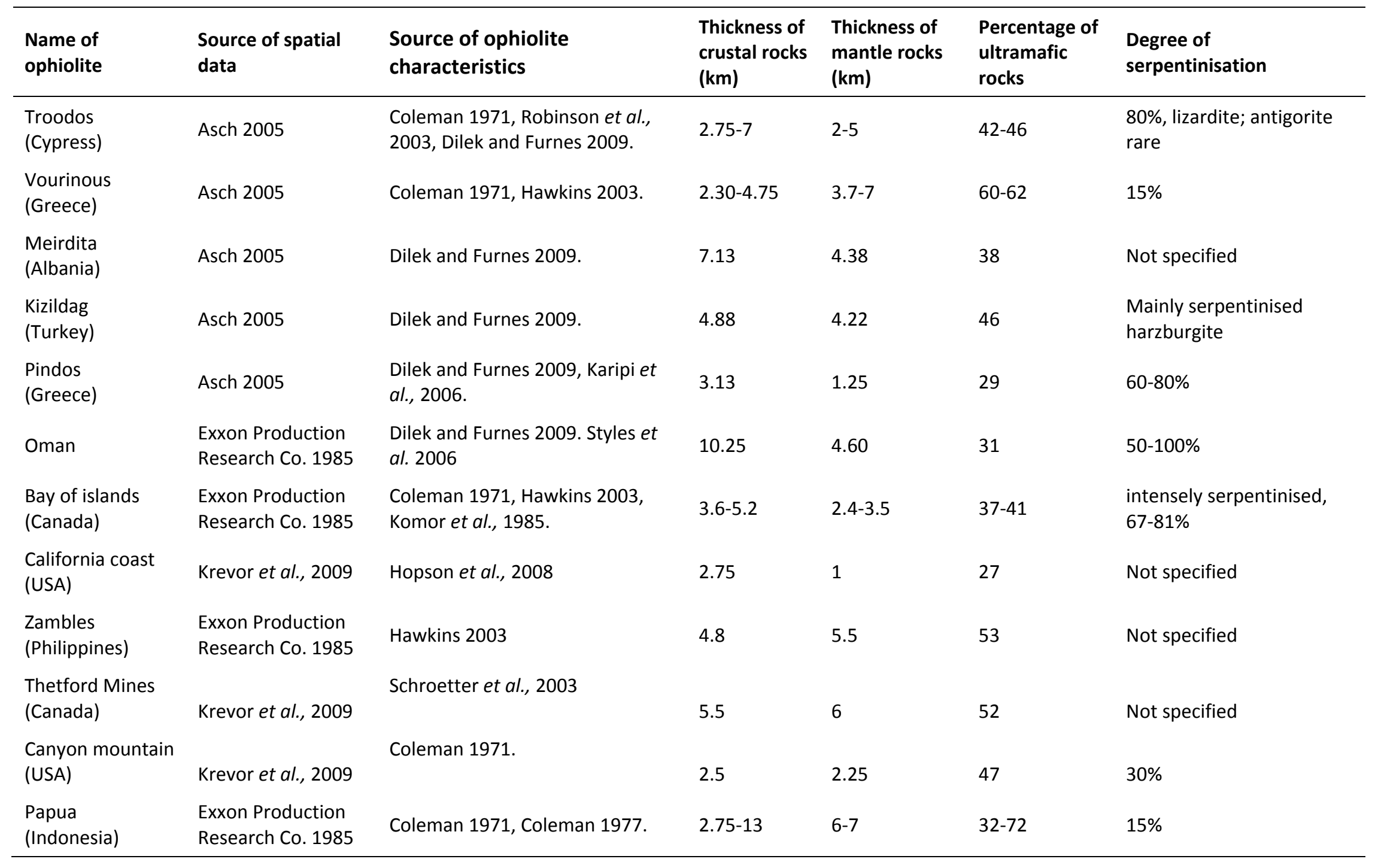




\begin{tabular}{lllllr}
\hline New Caledonia & $\begin{array}{l}\text { Exxon Production } \\
\text { Research Co. 1985 }\end{array}$ & Coleman 1971, Ulrich et al., 2010. & $0-4.5$ & $0.95-7.75$ & $78-100$ \\
$\begin{array}{l}\text { Typical ocean } \\
\text { crust }\end{array}$ & $\begin{array}{l}\text { Exxon Production } \\
\text { Research Co. 1985 }\end{array}$ & Hawkins 2003, Coleman 1971. & $4.5-6.5$ & $4.5-5.5$ & $46-50$ \\
\hline
\end{tabular}

Table 4. Compilation of characteristics of ophiolitic rocks in relation to CCSM feedstock materials. 


\begin{tabular}{ll}
\hline MgO content & Alteration product \\
\hline$>35 \%$ & Brucite (a magnesium hydroxide) \\
$25-35 \%$ & Serpentine group minerals \\
$<25 \%$ & Chlorite group minerals \\
\hline
\end{tabular}

Table 5. Relationship of $\mathrm{MgO}$ content to alteration product in komatiites, based on Arndt et al. (2008).

\begin{tabular}{lll}
\hline Name & \% Komatiite & Source \\
\hline Lapland & $20-30$ & Ernst and Buchan 2001 \\
Hattu & 10 & Ernst and Buchan 2001 \\
Kuhmo & 5 & Ernst and Buchan 2001 \\
Kostomuksha & $20-30$ & Ernst and Buchan 2001 \\
Eastern Dharwar & 10 & Ernst and Buchan 2001 \\
Sumozero-Kenozero & 10 & Ernst and Buchan 2001 \\
Belingwe greenstone belt & 5 & Ernst and Buchan 2001 \\
Olondo greenstone belt & 15 & Ernst and Buchan 2001 \\
Verkhovtsevo greenstone belt & 7 & Ernst and Buchan 2001 \\
Nondweni & 17 & Ernst and Buchan 2001 \\
Pietersburg & 15 & Ernst and Buchan 2001 \\
Seerteng & 5 & Ernst and Buchan 2001 \\
Kolar & 10 & Mani et al., 2008 \\
Chitadurga & 1 & Mani et al., 2008 \\
\hline
\end{tabular}

Table 6. Percentage of komatiite rocks in Archaean greenstone belts.

\begin{tabular}{|c|c|c|}
\hline Name & Serpentine minerals & Degree of serpentinisation \\
\hline $\begin{array}{l}\text { Black Swan (Norseman- } \\
\text { Wiluna Greenstone Belt) }\end{array}$ & Both types & $\begin{array}{l}\text { Minor (mainly carbonate } \\
\text { minerals) }\end{array}$ \\
\hline $\begin{array}{l}\text { Honeymoon Well (Norseman- } \\
\text { Wiluna Greenstone Belt) }\end{array}$ & Lizardite & Wholesale: No fresh olivine \\
\hline $\begin{array}{l}\text { Kambalda (Norseman-Wiluna } \\
\text { Greenstone Belt) }\end{array}$ & $\begin{array}{l}\text { None - amphibolite-facies grade } \\
\text { metamorphism }\end{array}$ & None \\
\hline $\begin{array}{l}\text { Marshall Pool (Norseman- } \\
\text { Wiluna Greenstone Belt) }\end{array}$ & Lizardite & $\begin{array}{l}\text { Appreciable: local preservation } \\
\text { of fresh olivine }\end{array}$ \\
\hline $\begin{array}{l}\text { Mt Keith (Norseman-Wiluna } \\
\text { Greenstone Belt) }\end{array}$ & $\begin{array}{l}\text { Mainly lizardite, lesser } \\
\text { antigorite }\end{array}$ & Appreciable \\
\hline $\begin{array}{l}\text { Perseverance (Norseman- } \\
\text { Wiluna Greenstone Belt) }\end{array}$ & $\begin{array}{l}\text { Amphibolite-facies grade } \\
\text { metamorphism with some } \\
\text { retrogressive serpentinisation }\end{array}$ & Variable \\
\hline $\begin{array}{l}\text { Scotia (Norseman-Wiluna } \\
\text { Greenstone Belt) }\end{array}$ & Antigorite & Appreciable \\
\hline $\begin{array}{l}\text { Walter Williams (Norseman- } \\
\text { Wiluna Greenstone Belt) }\end{array}$ & Lizardite & Appreciable: locally fresh olivine \\
\hline $\begin{array}{l}\text { Widgiemooltha (Norseman- } \\
\text { Wiluna Greenstone Belt) }\end{array}$ & $\begin{array}{l}\text { None - amphibolite-facies grade } \\
\text { metamorphism }\end{array}$ & None \\
\hline $\begin{array}{l}\text { Yakabindie (Norseman- } \\
\text { Wiluna Greenstone Belt) }\end{array}$ & 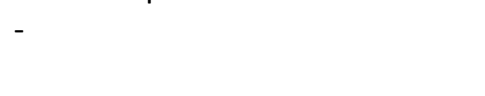 & Appreciable \\
\hline $\begin{array}{l}\text { Munro and Beatty ( Abitibi } \\
\text { Greenstone Belt) }\end{array}$ & - & Appreciable \\
\hline Abitibi Belt & - & Appreciable \\
\hline Belingwe Belt & - & Appreciable \\
\hline Khumo Belt & $\begin{array}{l}\text { None - amphibolite-facies grade } \\
\text { metamorphism }\end{array}$ & None \\
\hline
\end{tabular}


Table 7. Serpentine minerals in komatiites. Source: Barnes 2000 (unless otherwise stated) - denotes not specified. * Source Stiegler et al., (2010). For the location of the greenstone belts see Figure 5.

\begin{tabular}{lll}
\hline & \multicolumn{2}{l}{ layered igneous intrusions } \\
\cline { 2 - 3 } & Source: BGS dataset & Source: NRCAN \\
\hline Average size of intrusion & $2000 \mathrm{~km}^{2}$ & $100 \mathrm{~km}^{2}$ \\
Number of intrusions & 47 & 1040 \\
Total area & $94,000 \mathrm{~km}^{2}$ & $104,000 \mathrm{~km}^{2}$ \\
Area of ultramafic rocks (15\%) & $14,100 \mathrm{~km}^{2}$ & $15,600 \mathrm{~km}^{2}$ \\
Volume of ultramafic rocks (100m depth) & $493 \mathrm{~km}^{3}$ & $546 \mathrm{~km}^{3}$ \\
Weight of ultramafic rocks (100m depth) & 1,580 billion tonnes & 1,750 billion tonnes \\
\hline
\end{tabular}

Table 8 Resources of ultramafic rocks in layered igneous intrusions.

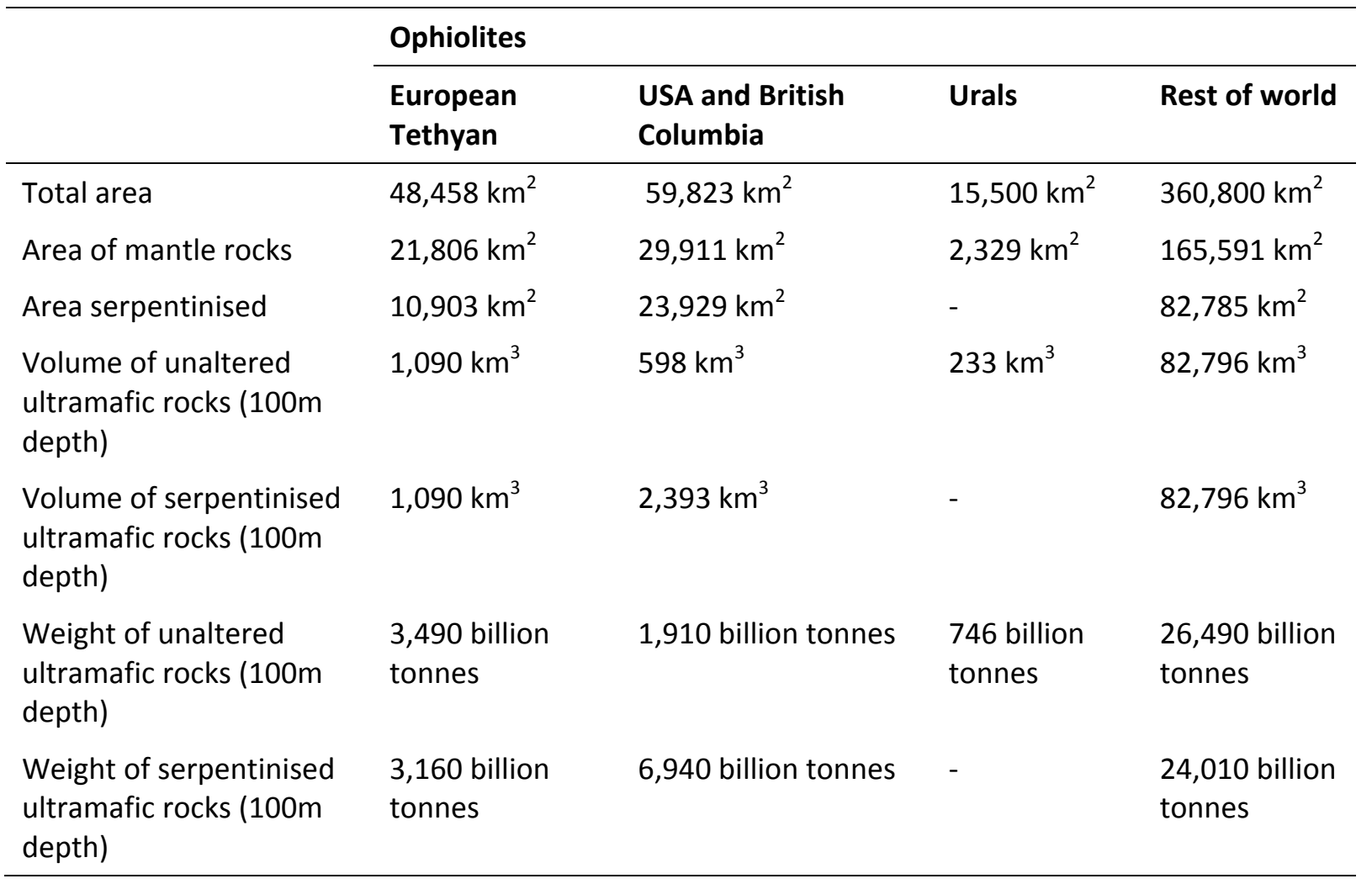

Table 9 Resources of ultramafic rocks in ophiolite rocks.

\section{Archaean greenstone belts}

Total area of prospective Archaean rocks

$7,659,841 \mathrm{~km}^{2}$

Area of ultramafic rocks within greenstone belts

$153,197 \mathrm{~km}^{2}$ 


\begin{tabular}{ll}
\hline Area of serpentinised ultramafic rocks & $76,589 \mathrm{~km}^{2}$ \\
Volume of serpentinised ultramafic rocks (100m depth) & $7660 \mathrm{~km}^{3}$ \\
Weight of serpentinised ultramafic rocks (100m depth) & 22,210 billion tonnes \\
\hline
\end{tabular}

Table 10 Resources of ultramafic rocks in Archaean greenstone belts.

\begin{tabular}{|c|c|c|c|c|}
\hline & \multicolumn{3}{|l|}{ Geological setting } & \multirow[b]{2}{*}{ Subtotals } \\
\hline & $\begin{array}{l}\text { Layered igneous } \\
\text { intrusions (BGS } \\
\text { data) }\end{array}$ & $\begin{array}{l}\text { Ophiolites } \\
\text { (including Urals) }\end{array}$ & $\begin{array}{l}\text { Archaean } \\
\text { greenstone belts }\end{array}$ & \\
\hline $\begin{array}{l}\text { Weight of serpentinised } \\
\text { ultramafic rocks ( } 100 \mathrm{~m} \\
\text { depth) (billion tonnes) }\end{array}$ & & 34,100 & 22,200 & 56,300 \\
\hline $\begin{array}{l}\text { Weight of unaltered } \\
\text { ultramafic rocks ( } 100 \mathrm{~m} \\
\text { depth) (billion tonnes) }\end{array}$ & 1,600 & 32,600 & & 34,200 \\
\hline Total for all ultramafic ro & cks (100m depth) ( & illion tonnes) & & 90,700 \\
\hline
\end{tabular}

Table 11 Summary of global resources of ultramafic rocks. Figures rounded to nearest 100 billion tonnes.

\section{List of figures}

Figure 1. Global distribution of sedimentary basins (USGS 2013)

Figure 2. A comparison of major layered igneous intrusions, adapted from Wilson, 1996, Annells, 1986a and Irvine and Smith, 1967

Figure 3. The distribution of resources of feedstock material from layered igneous intrusions based on BGS and NRCAN data.

Figure 4. The distribution of resources of feedstock material from ophiolites

Figure 5. The distribution of resources of feedstock material from Archaean rocks

Figure 6. Ultramafic rocks and $\mathrm{CO}_{2}$ emitters of southern Europe 


\section{References}

Annells, R.N., Fletcher, C.J.N., Burton, C.C.J. and Evans, R.B. 1986a the Rincón del Tigre Igneous Complex: a layered ultramafic-mafic intrusion of Upper Proterozoic age in the Precambrian Shield of eastern Bolivia. Part 1: geology and mineral potential (with 1:100,000 scale geological map). Overseas Geology and Mineral Resources 63, pp. 1-24.

Annells, R.N., Fletcher, C.J.N., Styles, M.T. and Harding, R.R. 1986b the Rincón del Tigre Igneous Complex: a layered ultramafic-mafic intrusion of Upper Proterozoic age in the Precambrian Shield of eastern Bolivia. Part 2: mineralogy and petrology (with 1:100,000 scale geological map). Overseas Geology and Mineral Resources 63, pp. 25-63.

Arndt, N.T., Lesher, C.M. and Barnes, S.J. 2008. Komatiite. 467 pp. Cambridge, New York, Melbourne: Cambridge University Press.

Asch, K. 2005. The 1:5 million International Geological Map of Europe and Adjacent Areas. BGR (Hannover) available from: http://www.bgr.de/karten/IGME5000/igme5000.htm

Barnes, S.J. 2000. Chromite in komatiites, II. Modification during Greenschist to mid-amphibolite facies metamorphism. Journal of Petrology 41 (3), pp. 387-409.

Barnes, S.J. and Hoatson, D.M. 1994. The Munni Munni complex, Western Australia: Stratigraphy, Structures and Petrogenesis. Journal of Petrology 35 (3), pp. 715.

Barnes, S. J., McIntyre, J.R., Nisbet, B.W. and Williams, C.R. 1990. Platinum group element mineralisation in the Munni Munni Complex, Western Australia. Mineralogy and Petrology 42, pp. 141-164.

Blais, S. and Auvray, B. 1990. Serpentinization in the Archean komatiitc rocks of the Khumo Greenstone Belt, Eastern Finland. Canadian Mineralogist 28, pp. 55-66.

Bodénan, F., Balilly, L., Piantone, P., Seron, A. and Touzé, S. 2006. Carbonation minérale - Potentiels in ex-situ, analyse bilantille et expérimentations en laboratoire. BRGM.

BP. 2013. BP statistical review of world energy June 2013. Available from www.bp.com

British Geological Survey. 2013. World mineral production 2007-2011. Keyworth, Nottingham: British Geological Survey

Cawthorn, R.G., Merkle, R.K.W. and Viljoen, M.V. 2002. Platinum-group element deposits in the Bushveld Complex, South Africa. In: The Geology, Geochemistry, Mineralogy and Mineral Beneficiation of Platinum Group Elements. Cabri, L.J. (Ed.) Canadian Institute of Mining Metallurgy and Petroleum, special publication no. 54, pp. 389-430.

Coleman, R.G. 1971. Plate tectonic emplacement of upper Mantle Peridotites along continental edges. Journal of Geophysical Research 76, pp. 1212-1222.

Coleman, R.G. 1977. Ophiolites ancient oceanic lithosphere? Springer-Verlag Berlin. 
Commission for the Geological Map of the World. 2000. Geological map of the World Scale 1:25 000000 , second edition. CGMW- UNESCO.

Dilek, Y. and Furnes, H. 2009. Structure and geochemistry of Tethyan ophiolites and their petrogenesis in subduction rollback systems. Lithos 113, pp. 1-20.

Eales, H.V. and Cawthorn, R.G. 1996. The Bushveld Complex. In: Cawthorn R.G. (Ed.) Layered igneous intrusions. Elsevier Science B. V., pp. 181-229.

Ernst, R.E. and Buchan, K.L. 2001. Larger mafic magmatic events through time and links to mantle plume-heads. In: Mantle Plumes: their identification through time. Ernst R.E. and Buchan K.L (Eds.) Geological Society of America Special Paper 352. Chapter 19.

Exxon Production Research Company and The American Association of Petroleum Geologists. 1985. Tectonic map of the World 1:10000000. Houston, Texas: Exxon Production Research Company.

Geological Survey of India. 1993. Geological map of India 1:5000000. Government of India.

Global Carbon Project. 2012. Carbon budget and trends 2012.

www.globalcarbonproject.org/carbonbudget] released on 3 December 2012.

Gislason, S.R., Wolff-Boenisch, D., Stefansson, A., Oelkersb, E.H., Gunnlaugsson, E., Sigurdardottir, H., Sigfusson, B., Broecker, W.S., Matter, J.M., Stute, M., Axelsson, G. and Fridrikssone, T. 2010. Mineral sequestration of carbon dioxide in basalt: a pre injection overview of the CarbFix project. International journal of greenhouse gas control 4 (3), pp. 537-545.

Gunn, A.G. 2014. Platinum group metals. In: Gunn, A.G. (ed), Critical Metals Handbook. Wiley and the American Geophysical Union, pp. 284-310.

Hawkins, J.W. 2003. Geology of supra-subduction zones-implications for the origin of ophiolites. In: Dilek, Y. and Newcomb, S. (Eds.), Ophiolite concept and the evolution of geological thought. Boulder Colorado, Geological Society of America Special Paper 227, pp. 227-268.

Highley, D.E., Chapman, G.R. and Bonel, K.A. 2004. The economic importance of minerals to the UK. British Geological Survey Commissioned Report. CR/04/070N. 32pp.

Hitch, M., Dipple, G.M. 2012. Economic feasibility and sensitivity analysis of integrating industrialscale mineral carbonation into mining operations. Minerals Engineering, 39, pp. 268-275.

Hopson, C.A., Mattinson, J.M., Pessagno, E.A. and Luyendyk, B.P. 2008. California Coast Range ophiolite: Composite Middle and Late Jurassic oceanic lithosphere. In: Wright, J.E. and Shervais, J.W. (Eds.) The Geological Society of America Special Paper 438.

IEA GHG 2006. Global IEA GHG CO2 Emissions Database: http://www.co2captureandstorage.info/co2emissiondatabase/co2emissions.htm

IPCC, 2005: IPCC Special Report on Carbon Dioxide Capture and Storage. Prepared by Working Group III of the Intergovernmental Panel on Climate Change [Metz, B., Davidson, O., de Coninck, H., Loos, M. and Meyer, L. (eds.)]. Cambridge University Press, Cambridge, United Kingdom and New York, NY, USA, $442 \mathrm{pp}$. 
Irvine, T.N. and Smith, C.H. 1967. The ultramafic rocks of the Muskox Intrusion Northwest Territories, Canada. In: Whllie P.J. (Ed.), Ultramafic and related rocks. John Wiley and sons inc., New York, London, Sydney. pp. 38-49.

Jahns, H. 1967. Serpentinites of the Roxbury District, Vermont. In: Whllie P.J. (Ed.), Ultramafic and related rocks. John Wiley and sons inc., New York, London, Sydney. pp. 137-160.

Karipi, S., Tsikouras, B. and Hatzipanagiotou, K. 2006. The petrogenesis and tectonic setting of ultramafic rocks from Iti and Kallidromon Mounitns, continental central Greece: vestiges of the Pindos Ocean. Canadian Mineralogist, 44 (1), 267-287

Matter, J.M. and Kelemen, P.B. 2009. Permanent storage of carbon dioxide in geological reservoirs by mineral carbonation. Nature Geoscience 2, pp. 837-841

Komor, S.C., Elthon, D. and Casey, J.F. 1985. Serpentinization of cumulate ultramafic rocks from the North Arm Mountain massif of the Bay of Islands ophiolite. Geochimica et Cosmochimica Acta 49, pp. 2331-2339.

Krevor, S.C., Graves, C.R., Van Gosen, B. and McCafferty, A. 2009. Mapping the mineral resource base for mineral carbon-dioxide sequestration in the conterminous United States. U.S. Geological Survey Digital Data Series 414. available at http://pubs.usgs.gov/ds/414

Lackner, K.S., Diby, P.F., Tuncel, Y., Krevor, S. and Graves, C. 2008. Integrating steel production with mineral sequestration. TRP 9957. AISI/DOE Technology roadmap program for the steel industry. http://www.osti.gov/bridge

Lackner, K.S., Wendt, C.H., Butt, D.P., Joyce, E.L. and Sharp, D.H. 1995. Carbon dioxide disposal in carbonate minerals. Energy 20, pp. 1154-1170.

Le Maitre, R.W. and Sabine, P.A. 2002. Igneous rocks: a classification and glossary of terms: recommendations of the International Union of Geological Sciences Subcommission on the Systematics of Igneous Rocks. Cambridge University Press. 236pp.

MacDonald, A.M., Bonsor, H.C., Dochartaigh, B.É.ó., and Taylor, R.G. 2012. Quantitative maps of groundwater resources in Africa. Environmental Research Letters 7.

Mani, D., Nirmal Charan, S. and Kumar, B. 2008. Assessment of Carbon dioxide sequestration potential of ultramafic rocks in the greenstone belts of southern India. Current Science 94, pp. 53-59.

McBirney, A.R. 1996. The Skaergaard Intrusion. In: Cawthorn R.G. (Ed.) Layered igneous intrusions. Elsevier Science B. V., pp. 147-180.

McCallum, I.S. 1996. The Stillwater Complex. In: Cawthorn, R.G. ed. Layered igneous intrusions. Elsevier Science B. V., pp. 441-483.

Miller, J.D. 2011. Layered igneous intrusions of the Duluth Complex. Geological Society of America Field Guide 2, pp. 171-201.

Miller, J.D, and Ripley E.M. 1996. Layered intrusion of the Duluth Complex, Minnesota USA. In: Cawthorn, R.G. ed. Layered igneous intrusions. Elsevier Science B. V., pp. 257-301. 
Matter, J.M., Brecker, W.S., Stute, M., Gislason, S.R., Oelkers, E.H., Stefansson, A., Wolff-Boenisch, D., Gunnlaugsson, E., Axelsson, G. And BJörnsson, G. 2009. Permanent carbon dioxide storage into basalt: the CarbFix pilot project Iceland. Energy Procedia 1, pp. 3641-3646.

Moosdorf, N., Renforth, P. and Hartmann, J. 2014. Carbon dioxide efficiency of terrestrial enhanced weathering. Environment Science Technology, no. 48(9), pp. 4809-4816.

Natural Resources Canada. 2012: Mineral Deposit Database. Geoscience Data Repository. Geological Survey of Canada. Earth Sciences Sector. Natural Resources Canada. Government of Canada.

Available from: http://gdr.nrcan.gc.ca/minres/index e.php. Accessed 6/1/2012.

Nicolas, A. and Boudier, F. 2003. Where ophiolites come from and what do they tell us. In: Dilek, Y. and Newcomb S, (Eds.) Ophiolite concept and the evolution of geological thought: Boulder Colorado, Geological Society of America Special Paper 373, pp. 137-152.

Oberthür, T. 2002, Platinum-group element mineralization of the Great Dyke, Zimbabwe. In: The Geology, Geochemistry, Mineralogy and Mineral Beneficiation of Platinum Group Elements. Cabri, L.J. (Ed.) Canadian Institute of Mining Metallurgy and Petroleum, special publication no. 54, pp. 483506.

Onen, A.P. 2003. Neotethyan ophiolitic rocks of the Anatolides of NW Turkey and comparison with Tauride ophiolites. Journal of the Geological Society London 160 (6), pp. 947-962.

O'Connor, W.K., Dahlin, D.C., Rush, G.E., Gerdemann, S.J., Penner, L.R. and Nilsen, D.N. 2005. Aqueous Mineral Carbonation Final Report, Aqueous mineral carbonation: mineral availability, pretreatment, reaction parametrics and process studies, Albany Research Centre, DOE/ARC -TR-04-002, USA.

Picot, J.C., Cassard, D., Maldan, F., Greffié, C. and Bodénan, F. 2011. Worldwide potential for ex-situ mineral carbonation. Energy Procedia. 4, pp. 2971-2977

Prendergast, M.D. 2000. Mineralization in the Rincón del Tigre complex, Eastern Bolivia. Economic geology 95 (1), pp. 113-130.

Renforth, P. 2012. The potential of enhanced weathering in the UK. International Journal of Greenhouse Gas Control 10, pp. 229-243.

Renforth, P., Washbourne, C.L., Taylder, J. and Manning, D.A.C. 2011. Silicate production and availability for mineral carbonation. Environmental science and technology 45 (6), pp. 2035-2041.

Ragan, D.M. 1967. The Twin Sisters Dunite Washington. In: Whllie P.J. (Ed.) Ultramafic and related rocks. John Wiley and sons inc. New York, London, Sydney, pp. 160-167.

Robinson, P.T., Malpas, J. and Xenophontos, C. 2003 The Troodos Massif of Cyprus: its role in the evolution of the ophiolite concept. In Dilek, Y. and Newcomb ,S., (Eds.) Ophiolite concept and the evolution of geological thought: Boulder Colorado, Geological Society of America Special Paper 373, pp. 295-308. 
Sanna, A., Uinu, M., Caramanna, G., Kuusik, R. and Maroto-Valer, M.M. 2014a. A review of mineral carbonation technologies to sequester $\mathrm{CO}_{2}$. Chemical Society Reviews, In press.

Sanna, A, Lacinska, A.M., Styles, M.T. and Maroto-Valer, M.M. 2014b. Silicate rock dissolution by ammonium bisulphate for $\mathrm{pH}$ swing mineral $\mathrm{CO} 2$ sequestration. Fuel Processing Technology 120, 128-135.

Sanna, A., Dri, M., Hall, M.R. and Maroto-Valer M. 2012. Waste Materials as a Potential Resource for Carbon Capture and Storage by Mineralisation (CCSM) in the UK Context, Applied Energy, (DOI: 10.1016/j.apenergy.2012.06.049).

Schroetter, J., Page, P., Bedard, J.H., Tremblay, A. and Becu, V. 2003. Forearc extension and sea-floor spreading in the Thetford Mines Ophiolite Complex. In: Dilek, Y, and Robinson, P. T. (eds.) Ophiolites in earth history. Geological Society, London, special publications, 218, pp. 231-251.

Seifritz, W. 1990. CO2 Disposal by Means of Silicates, Nature, pp. 345, 486.

Schuiling, R.D. and Krijgsman, P. 2006. Enhanced weathering: an effective and cheap tool to sequester $\mathrm{CO}_{2}$. Climate Change 74 (1-3), pp. 349-354.

Stiegler, M.T., Lowe, D.R. and Byerly, G.R. 2010. The petrogenesis of volcaniclastic komatiites in the Barberton greenstone Belt, South Africa: a textural and ground study. Journal of Petrology 51 (4), pp. 947-972.

Styles, M.T., Sanna, A., Lacinska, A.M., Naden, J. and Maroto-Valer, M. 2014. The variation in composition of ultramafic rocks and the effect on their suitability for carbon dioxide sequestration by mineralisation following acid leaching. Greenhouse Gases Science and Technology (4) pp.440-451.

Styles, M.T., Ellison, R.A., Arkley, S.L.B., Crowley, Q., Farrant, A., Goodenough, K.M., McKervey, J.A., Pharoah, TC., Phillips, E.R., Schofield, D. and Thomas, R.J. (2006). The geology and geophysics of the United Arab Emirates.Volume 2: Geology. Keyworth, Nottingham: British Geological Survey, 351 pp.

Teir, S., Kuusik, R., Fogelholm, C.J. and Zevenhoven, R. 2007. Production of magnesium carbonates from serpentinite for long-term storage of $\mathrm{CO}_{2}$. Int. J. Miner. Proc. 85, pp. 1-15.

Ulrich, M., Picard, C., Guillot, S., Chauvel,. C., Cluzel, D. and Meffre, S. 2010. Multiple melting stages and refertilization as indicators for ridge to subduction formation: the New Caledonian ophiolite. Lithos 115, pp. 223-236.

U.S. Geological Survey World Conventional Resources Assessment Team. 2013. Supporting data for the U.S. Geological Survey 2012 world assessment of undiscovered oil and gas resources: U.S. Geological Survey Digital Data Series DDS-69-FF, various pages, http://pubs.usgs.gov/dds/dds069/dds-069-ff/.

Verta, R. L. 2013. Wollastonite commodity summary 2013. USGS. Available from: http://minerals.usgs.gov/minerals/pubs/commodity/wollastonite/

Voormeij, D.A. and Simandl, G.J. 2004. Ultramafic rocks in British Columbia: Delineating Targets for Mineral Sequestration of $\mathrm{CO}_{2}$. British Columbia Ministry of Energy, Mines and Petroleum Resources, pp. 157-167. 
Wilson, A.H. 1996. The Great Dyke of Zimbabwe. In: Cawthorn, R.G. (Ed.). Layered igneous intrusions. Elsevier Science B. V., pp. 365-402.

Wilson, A.S., Dipple, G.M., Power, I.M., Thom, J.M., Anderston, R.G., Raudsepp. M., Gabites, J.E. and Southam, G. 2009. Carbon dioxide fixation within mine wastes of ultramafic-hosted ore deposits: Examples from the Clinton Creek and Cassiar chrysotile deposits, Canada. Economic Geology 104, pp. 95-112.

Zientek, M.L., Cooper, R.G., Corson, S.R. and Geraghty, E.P. 2002. Platinum-Group Element Mineralization in the Stillwater Complex, Montana. In: The Geology, Geochemistry, Mineralogy and Mineral Beneficiation of Platinum Group Elements. Cabri, L.J. (Ed.) Canadian Institute of Mining Metallurgy and Petroleum, special publication no. 54, pp. 459-482.

Zevenhoven, R., Fagerlund, J. and Songok, J.K. 2011. CO2 mineral sequestration: developments toward large-scale application Greenhouse Gas Sci Technol. 1:48-57 (2011); DOI: 10.1002/ghg3

Zohan, Z. 2002. Alaskan-type complexes and their platinum-group element mineralization. In: The Geology, Geochemistry, Mineralogy and Mineral Beneficiation of Platinum Group Elements. Cabri, L.J. (Ed.) Canadian Institute of Mining Metallurgy and Petroleum, special publication no. 54, pp. 669719. 


\section{Figures}

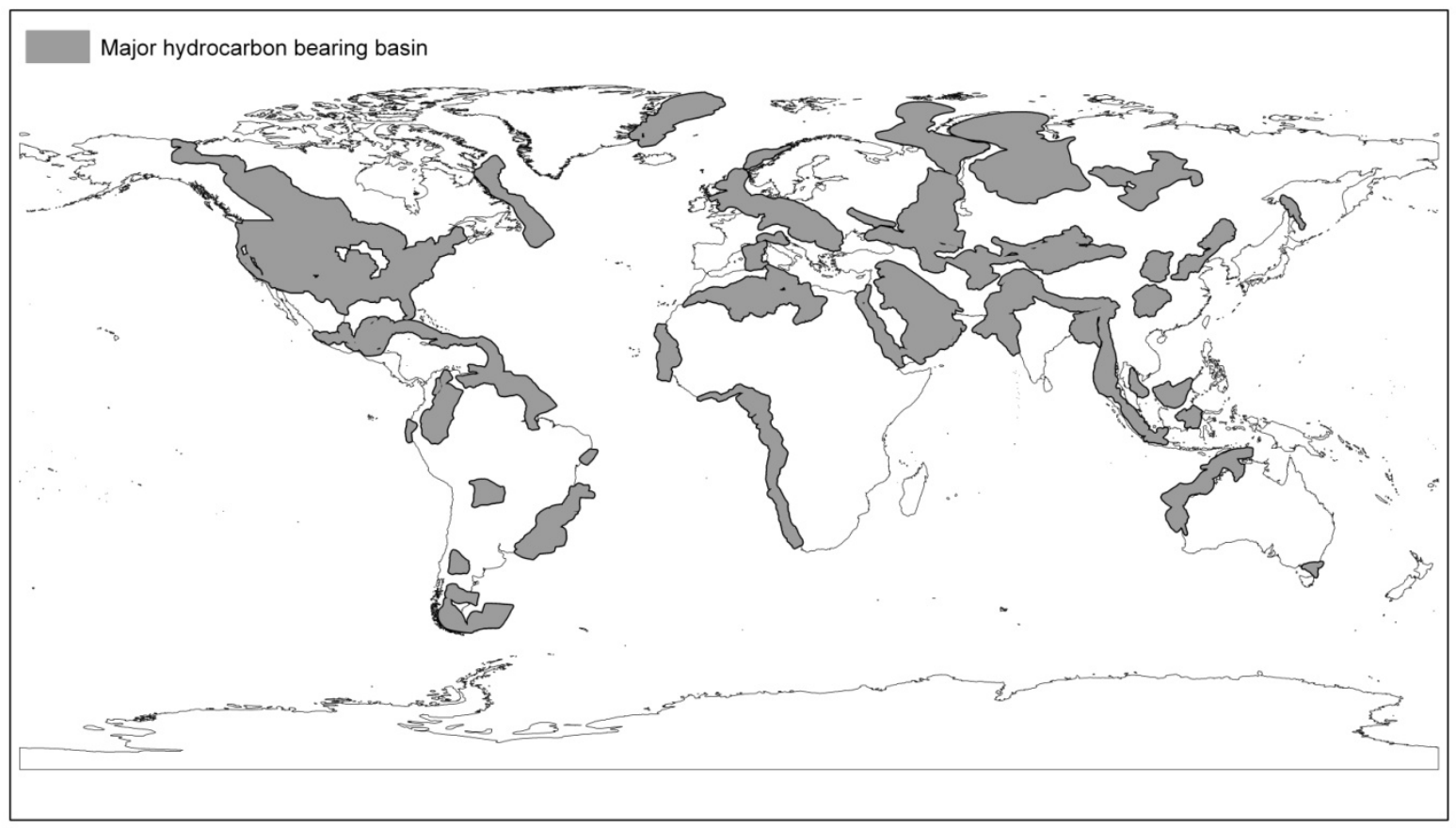

Figure 7. Global distribution of sedimentary basins (USGS 2013) 


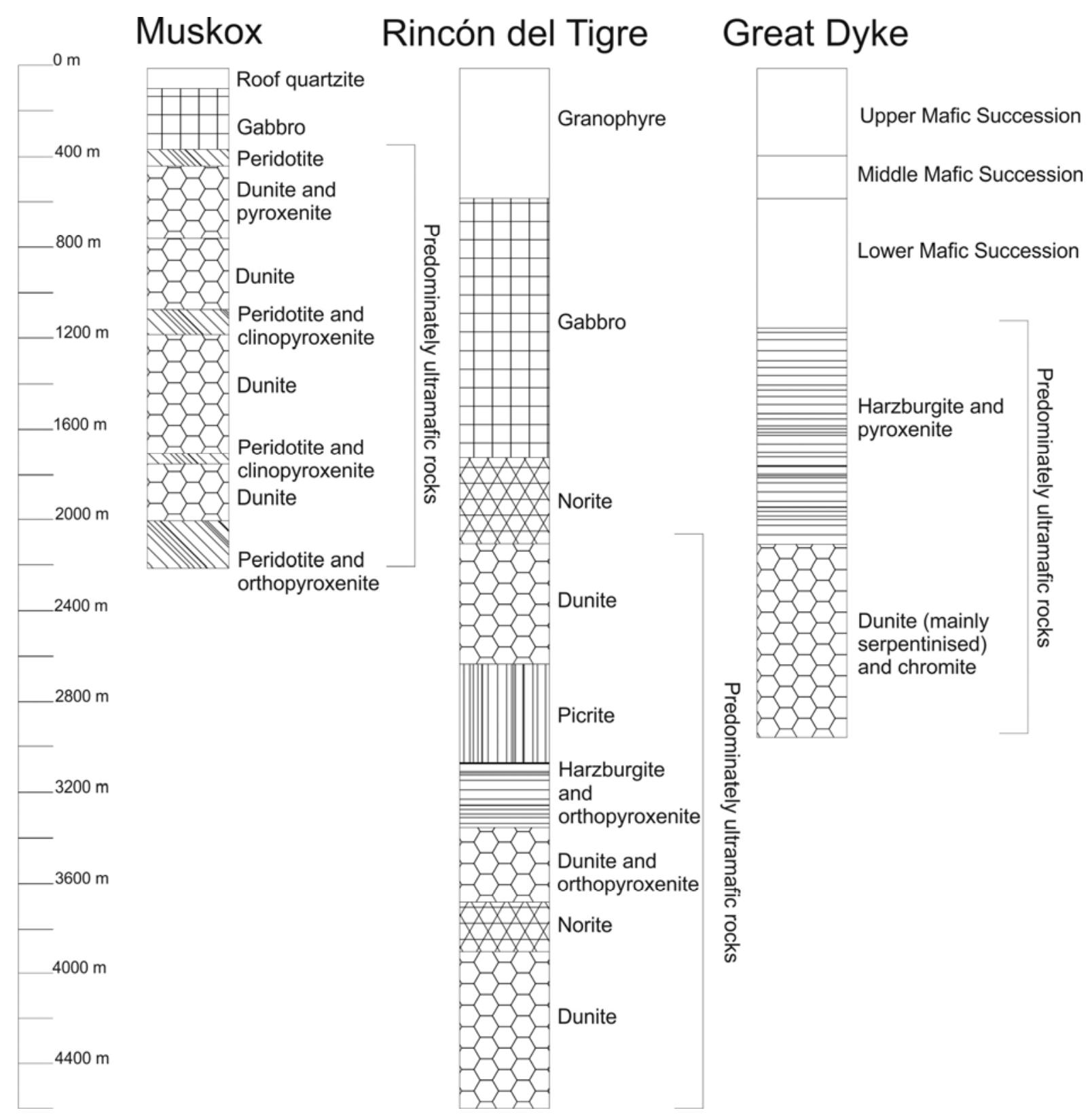

Figure 8. A comparison of major layered igneous intrusions, adapted from Wilson, 1996, Annells, 1986a and Irvine and Smith, 1967 


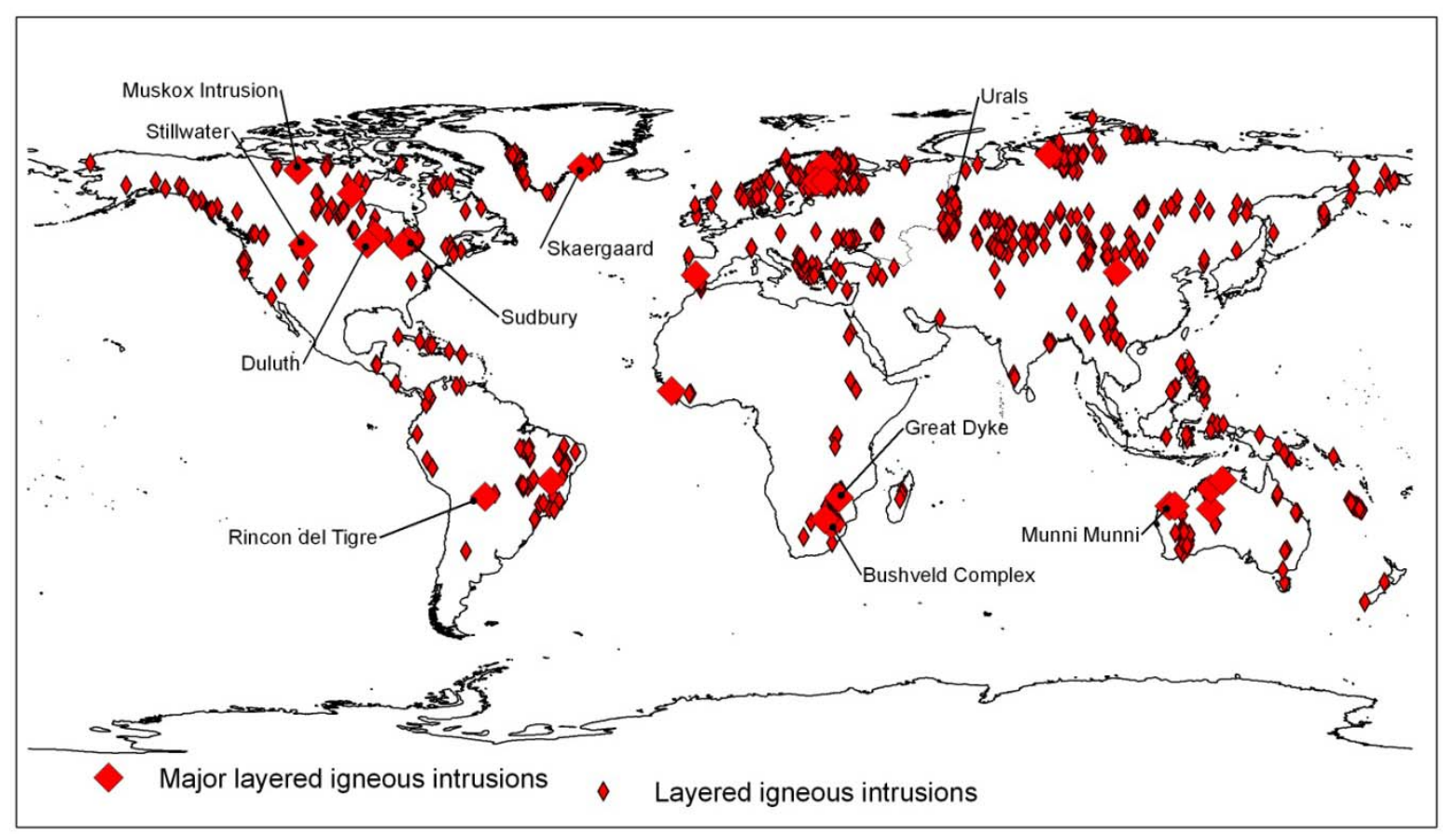

Figure 9. The distribution of resources of feedstock material from layered igneous intrusions based on BGS data.

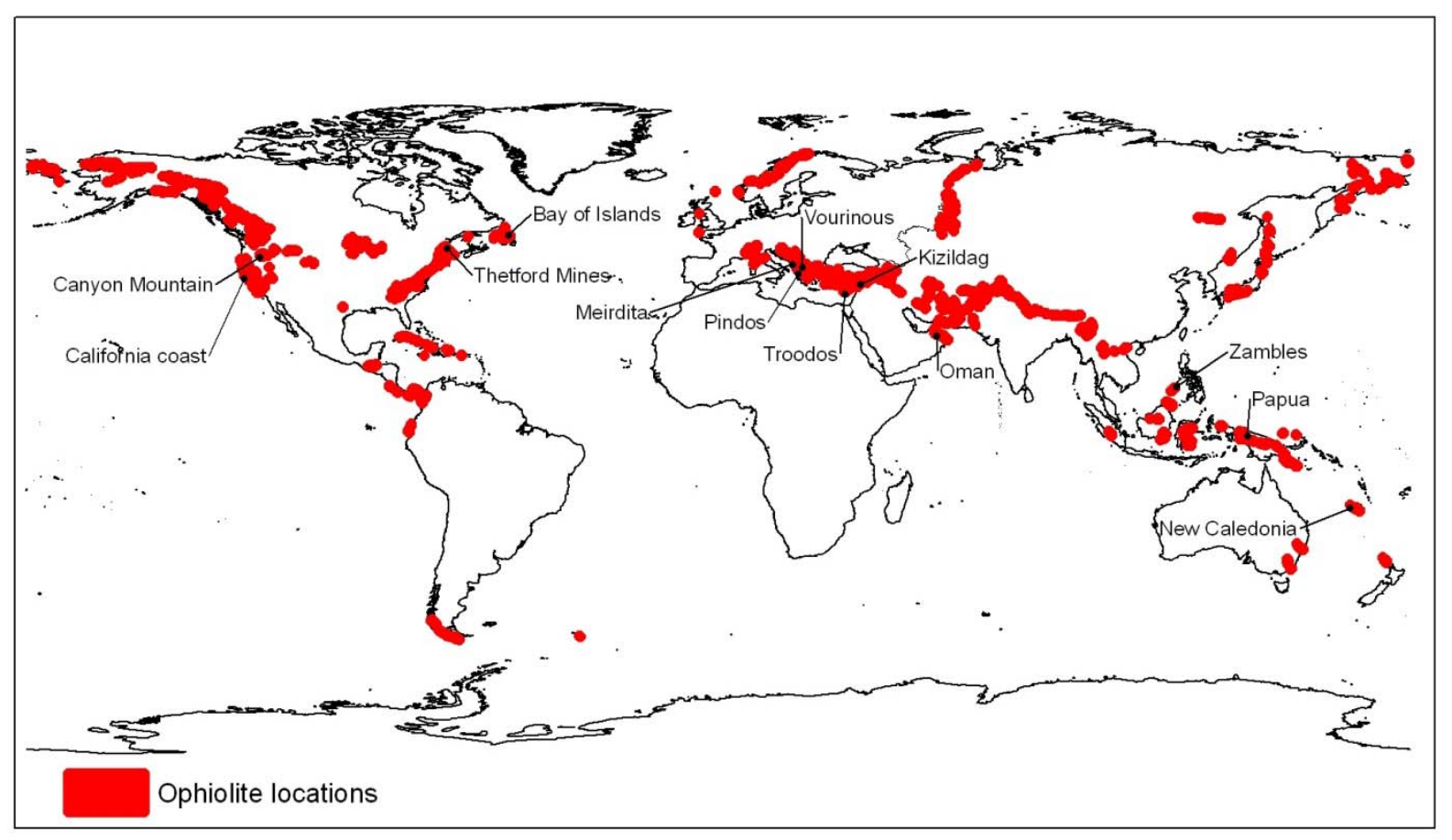

Figure 10. The distribution of resources of feedstock material from ophiolites. 


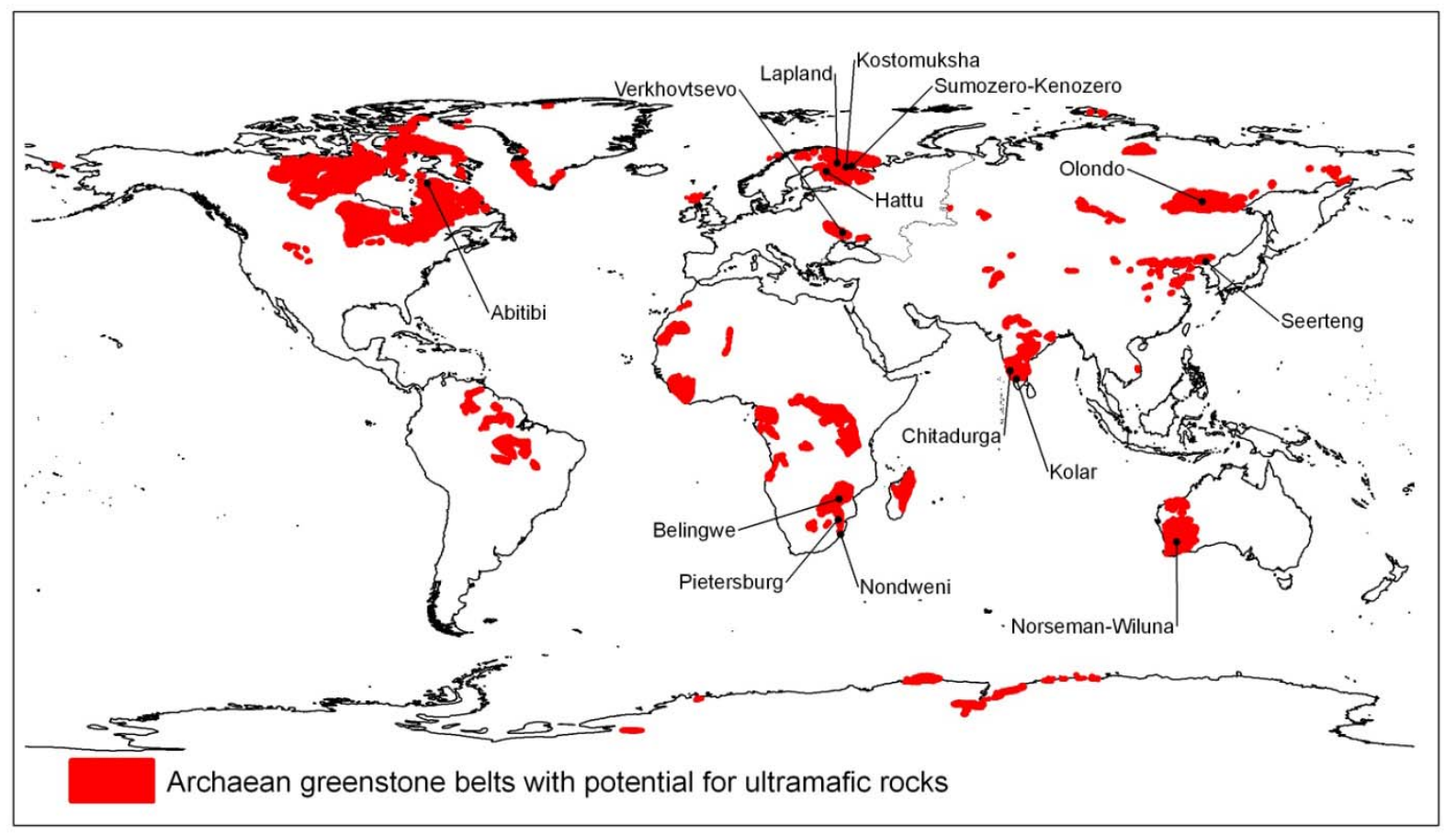

Figure 11. The distribution of resources of feedstock material from Archaean rocks.

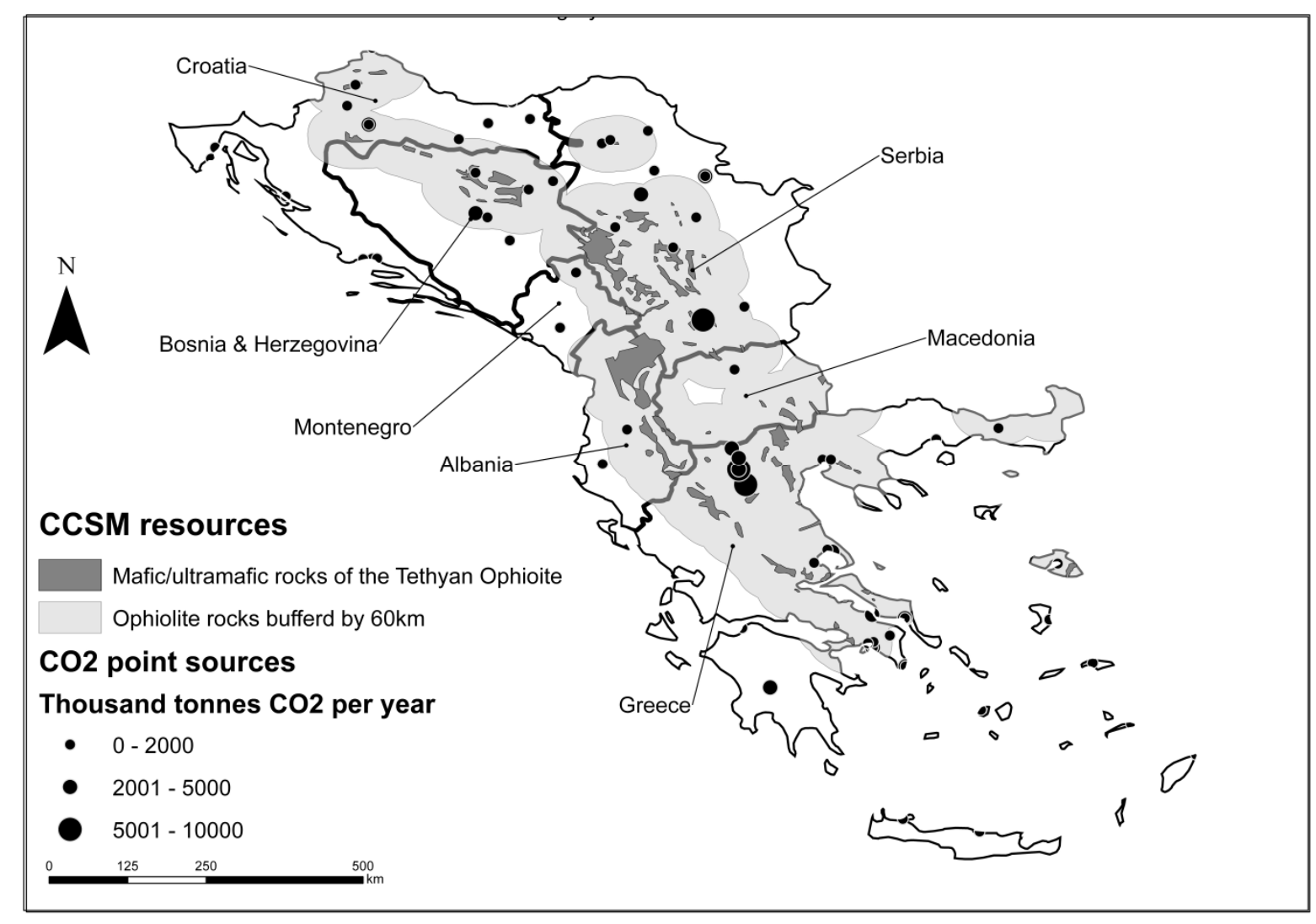

Figure 12 ultramafic rocks and $\mathrm{CO}_{2}$ emitters of southern Europe 